\title{
Comparative Aspects of Canine Melanoma
}

\author{
Adriana Tomoko Nishiya ${ }^{1}$, Cristina Oliveira Massoco ${ }^{1}$, Claudia Ronca Felizzola ${ }^{1,2}$, \\ Eduardo Perlmann ${ }^{3}$, Karen Batschinski ${ }^{1}$, Marcello Vannucci Tedardi ${ }^{1}$, Jéssica Soares Garcia ${ }^{1}$, \\ Priscila Pedra Mendonça ${ }^{3}$, Tarso Felipe Teixeira ${ }^{4}$ and Maria Lucia Zaidan Dagli ${ }^{1}$ ** \\ 1 Department of Pathology, School of Veterinary Medicine and Animal Science, University of São Paulo, \\ Av. Prof. Dr. Orlando Marques de Paiva, 87, CEP 05508-270, São Paulo, Brazil; adrinishiya@usp.br (A.T.N.); \\ cmassoco@gmail.com (C.O.M.); cfronca@globo.com (C.R.F.); karen.batschinski@gmail.com (K.B.); \\ Marcello.tedardi@usp.br (M.V.T.); jessica.sg@hotmail.com (J.S.G.) \\ 2 Surgical Oncology Rua Antônio Alves Magan, 124, CEP 01251-150, São Paulo, Brazil \\ 3 Department of Surgery, School of Veterinary Medicine and Animal Science, University of São Paulo, \\ CEP 05508-270, São Paulo, Brazil; perlmann@ig.com.br (E.P.); priscila.pedra@gmail.com (P.P.M.) \\ 4 Pathology Veterinary Medicine, FEPI Itajubá University Center, Dr. Antonio Braga Filho Street, 687, \\ Itajubá, 37.501-002 Minas Gerais, Brazil; tarsofelipe@hotmail.com \\ * Correspondence: mlzdagli@usp.br; Tel.: +55-011-3091-7712
}

Academic Editor: Jaime F. Modiano

Received: 19 August 2015; Accepted: 1 February 2016; Published: 19 February 2016

\begin{abstract}
Melanomas are malignant neoplasms originating from melanocytes. They occur in most animal species, but the dog is considered the best animal model for the disease. Melanomas in dogs are most frequently found in the buccal cavity, but the skin, eyes, and digits are other common locations for these neoplasms. The aim of this review is to report etiological, epidemiological, pathological, and molecular aspects of melanomas in dogs. Furthermore, the particular biological behaviors of these tumors in the different body locations are shown. Insights into the therapeutic approaches are described. Surgery, chemotherapy, radiotherapy, immunotherapy, and the outcomes after these treatments are presented. New therapeutic perspectives are also depicted. All efforts are geared toward better characterization and control of malignant melanomas in dogs, for the benefit of these companion animals, and also in an attempt to benefit the treatment of human melanomas.
\end{abstract}

Keywords: melanoma; canine; cancer; histopathology; therapy

\section{Introduction}

Melanoma is a malignant neoplasm originating from melanocytes. Melanocytic neoplasms have been described in men and in most domesticated animal species, including dogs, cats, horses, and also in wild terrestrial and marine animals [1].

Since dogs live in close proximity to humans, they are influenced by similar environmental factors that may lead to chronic diseases and cancer. In fact, the domestic dog (Canis familiaris) reportedly presents more naturally inherited chronic diseases than any other animal species. Hence, those aspects have to be considered in the selection of an animal model for a multifactorial human disease, and the dog appears to be the one with the best characteristics [2-4]. Dogs are considered recommended models due to their relatively high susceptibility to cancers, including melanomas, and many behavioral similarities [5].

While many genetic alterations of melanomas have recently been discovered and studied, control of this disease is still challenging in both humans and animals, particularly in dogs and cats. The aim of this review is to report a comparative approach of the etiological, epidemiological, pathological, and molecular aspects of melanomas in dogs. 


\section{Canine Melanoma Epidemiology}

Melanoma is one of the most devastating types of cancer, killing around 50,000 people worldwide every year [6,7]. In 2015, according to the American Cancer Society, it is estimated that about 73,870 new melanoma cases will be diagnosed (about 42,670 in men and 31,200 in women), and 9940 people are expected to die of melanoma (about 6640 men and 3300 women).

Human malignant mucosal melanoma of the head and neck is increasing rapidly in incidence in the United States. It is an uncommon and fatal malignancy that does not appear to have the same etiologic basis as cutaneous melanoma. In 452 observed cases, the majority of patients had sino-nasal location (72.6\%) and white women ages 70 or older were most affected [8]. This kind of human malignant melanoma is uncommon and has aggressive behavior with increasing rates of recurrence and regional and distant metastasis [9]. Regional lymphatic metastasis occurred in $57.9 \%$ to $21 \%$ of patients and recurrence rates were $57.9 \%$ to $26.3 \%$ for patients treated with surgery alone and for those treated with surgery and radiotherapy, respectively. Distant metastases occurred in 52.6\% receiving surgery alone and in $47.3 \%$ receiving both therapies [10].

Canine oral malignant melanomas in dogs accounted for $0.99 \%$ of all $(338 / 33826)$ canine pathology cases received from 1992 through 1999 at the University of Missouri-Veterinary. The most common sites are the gingiva and labial mucosa [11].

In a retrospective study of neoplasms in domestic animals (data collected between 1993 and 2002 at the School of Veterinary Medicine and Animal Science of the University of São Paulo, Brazil), of 1813 cases of neoplasms in dogs, 58 were melanocytic neoplasms, accounting for 3\% of the total in this species [12]. In another retrospective study, 2154 neoplasms were diagnosed at the University of São Paulo between 2000 and 2006. A total of 193 cases (8.9\%) were melanocytic neoplasms, of which 186 cases occurred in dogs (96.4\%), and only seven in cats (3.6\%). Male mixed-breed dogs with black hair coats, with ages varying from 8 to 11 years, were the most commonly affected animals [13].

Canine malignant melanomas are located at different anatomical sites, such as the mouth (Figure 1A,B), lips, skin (Figure 1C), eyes, and digits (Table 1). Studies are controversial about the most common location for this disease in dogs; however, most studies point to the oral cavity and skin as the most common sites [14-17]. In a survey of 384 melanocytic canine tumors, oral, cutaneous, lips/feet, and eye sites comprised 19\%,59\%, 19\%, and 3\%, respectively [18]. In another study considering malignant melanomas, oral cavity and cutaneous localization were the most common in $40 \%-62 \%$ and $27 \%-31 \%$, respectively $[13,19]$.

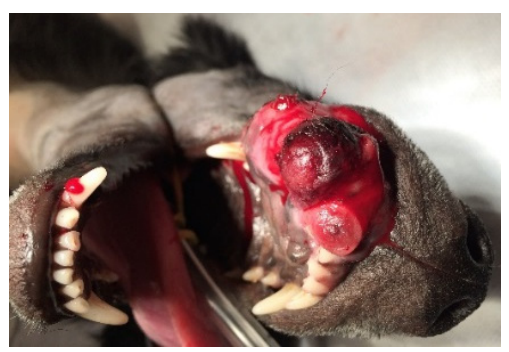

(A)

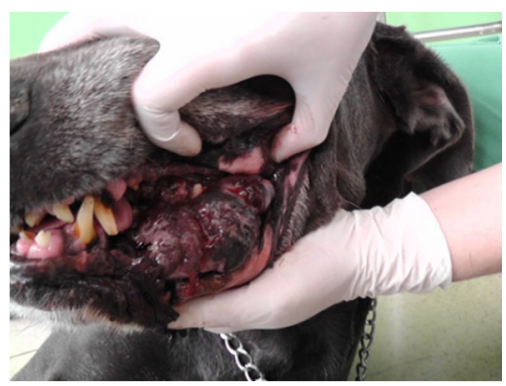

(B)

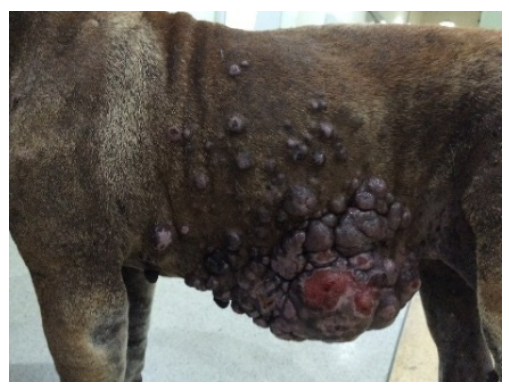

(C)

Figure 1. Clinical aspect of malignant oral melanomas (A) in maxilla; (B) in mandible. Clinical aspect of malignant cutaneous melanoma (C) in thoracic and abdominal wall (Adriana Nihiya). 
Table 1. Common sites of malignant melanomas in dogs.

\begin{tabular}{cccc}
\hline Sites/Total Number of Cases & $\boldsymbol{n = 1 6 5 2}$ & $\boldsymbol{n = 1 4 3}$ & $\boldsymbol{n = 2 0 9}$ \\
\hline Oral & 1026 & 57 & 67 \\
Cutaneous & 448 & 44 & 88 \\
Scrotum & - & 4 & - \\
Digit & 94 & 21 & - \\
Ungual & 60 & - & - \\
Ocular & 24 & 17 & 54 \\
Lips/Feet & - & - & Spangler and \\
Reference & Gillard et al., & Teixeira et al., & Kass, 2006 [18] \\
\hline
\end{tabular}

Data obtained from historical studies indicated that the following breeds of dogs are considered at risk to develop melanocytic tumors: Airedale Terrier, Boston Terrier, Boxer, Chihuahua, Chow Chow, Cocker Spaniel, Doberman Pinscher, English Springer Spaniel, Golden Retriever, Irish Setter [20], Miniature Schnauzer, Scottish Terrier [19,20], Poodles, Beauce Shepherds, Rottweilers, and Labrador Retrievers [19]. Some breeds of dogs, specifically the Schnauzer family (miniature and standard), Scottish Terriers, and Irish Setters are at risk for developing digital malignant melanomas [21,22].

Malignant melanomas typically occur in middle-aged to older dogs, as Miller et al. [23] found an average age of nine years, and with no gender predilections.

Teixeira et al. [24] studied 25 canine oral melanomas, including 16 melanotic and nine amelanotic specimens. In this study, $25 \%$ of the melanotic melanoma-bearing dogs were eight-year old animals, and $22.2 \%$ of amelanotic melanoma-bearing group were younger, with ages varying from four to eight years.

Most information on animal cancer epidemiology in the literature comes from laboratories or hospitals, usually from a unique center and using non-standard coding protocols. This may lead to epidemiological bias, and the data rarely generate reliable information useful to establish comparisons. Cancer registries are the most important source of epidemiological data for neoplasms [25]. There are some animal cancer registries around the world, situated mostly in Europe and the USA. In 2013, the São Paulo Animal Cancer Registry was created at the University of São Paulo, Brazil, serving as the first animal cancer registry in Latin America [25,26]. This system will allow for better and more accurate epidemiologic studies in domestic animals in this region.

\section{Canine Malignant Melanoma Etiology}

In humans, malignant melanoma is the most aggressive, therapy-resistant, and deadly form of skin cancer [27]. The major risk factors for human melanoma include family history, skin and mucosal pigmentation characteristics, sun exposure, particularly to UVB light, and skin reactions to sun exposure. Another type of melanoma, oral malignant melanoma, is a rare aggressive neoplasm usually seen in middle-aged adults.

Several etiological factors are supposed to be involved in canine malignant melanomas, including consanguinity, trauma, chemical exposure, hormones, and genetic susceptibility [28]. However, there is no consensus regarding the etiology of malignant melanomas in dogs [29]. Sunlight may be involved in the development of this disease in the sun-exposed skin areas of the body, such as the face and pinnae; however, sunlight probably is not involved in mucosal melanomas, like the ones found in the canine buccal cavity. Other factors, like the presence of pigmented cells, trauma, chemical agents, or even the buccal microbiota, and inflammation may be associated with the etiology of these tumors [30].

Although melanomas can arise in any dog, the prevalence of this disease is higher in purebred dogs, especially Standard and Miniature Schnauzers, Doberman Pinschers, Scottish Terriers, Irish and Gordon Setters, and Golden Retrievers. This fact supports the theory that melanomas in dogs could have a genetic basis [28]. Genetic and epigenetic modifications in melanocytes that lead to alterations 
in expression or function of genes and proteins involved in cell cycle control and apoptosis are certainly involved in the development of melanomas.

\section{Canine Melanoma Pathological Aspects and Prognosis}

Melanocytic neoplasms can be classified as benign or malignant tumors [31]. Malignant melanomas are considered malignant neoplasms arising from melanocytes, while melanocytomas are the benign counterparts [31].

Melanocytes, which are dendritic cells derived from the neuroectoderm and melanoblasts of the neural crest, migrate during embryogenesis to the dermis and epidermis, mucous membranes, and eyes [29,32]. These dendritic cells in melanoma development have demonstrated altered expression of cell-cell adhesion molecules, such as decreased expression of E-cadherin and V-CAM 1 and increased expression of N-cadherin, Mel-CAM 1, ICAM 1, and $\alpha \beta$ integrins [33]. The development of malignant melanoma is generally characterized by a series of transitions that are outlined in [34], and arises from melanocytes that normally reside within the basal layer of epidermis [35].

According to Head et al. [36], a melanocytoma is a benign tumor composed of melanocytes in the basal region of the epithelium and extending into the submucosa (junctional melanocytoma) or in the sub-epithelial connective tissue under normal epithelium (dermal melanocytoma). Malignant melanoma can be subdivided into three patterns on the basis of cell shape [36]:

- epithelioid—round and polygonal cells (Figure 2)

- $\quad$ spindle cell-tumor resembles fibroblasts

- mixed tumors-show both cell types

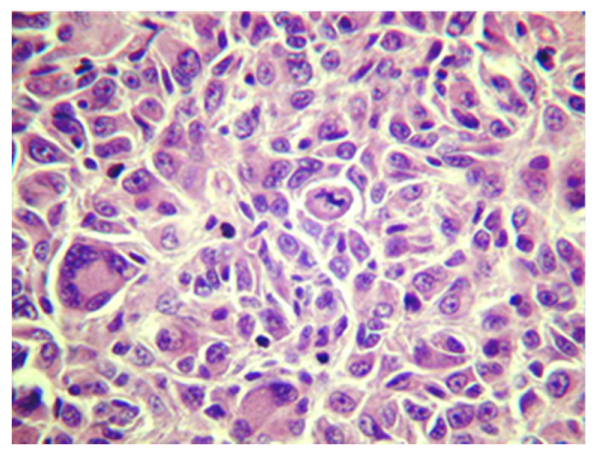

(A)

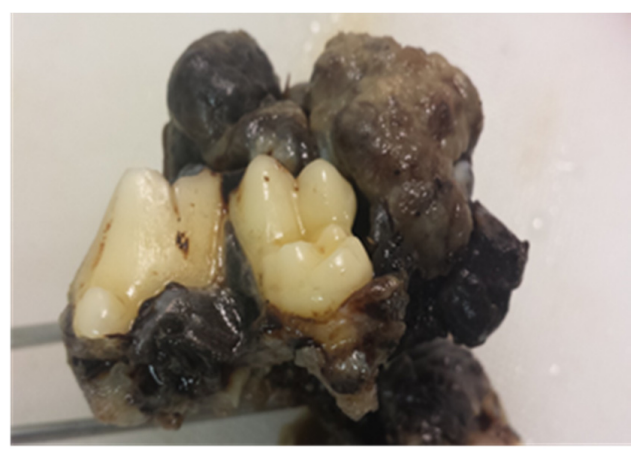

(B)

Figure 2. Photomicrograph of the most common histopathology type of malignant melanoma (epithelioid), showing formation of cell nests, with the presence of multinucleated giant cells and atypical mitotic figures, HE, Objective $40 \times(\mathbf{A})$. Canine oral malignant melanoma, pigmented, exophytic mass protruding from the gingiva (B). Formalin-fixed tissue. Photographs are courtesy of Professor Dr. José Guilherme Xavier.

Malignant melanoma histologically can be the highly melanotic type or the highly anaplastic amelanotic type. Anaplastic melanocytes can be large with abundant cytoplasm with one or more oval or elongated nuclei, with obvious nucleoli. These are frequently characterized to form nests in the submucosa by a mixed structure of epithelial-like cells and fusiform cells and junctional infiltration between basal cells and in the submucosa [36] (Figure 3).

The most prominent biological property of melanoma cells is the ability to produce melanin [37]. The disruption of homeostasis of close association between melanocytes and basal keratinocytes may trigger a continuous proliferation of the melanocytes, which may lead to the development of a malignant melanoma [7]. Once malignant melanoma cells have escaped from the keratinocyte control, they become able to invade the tissue by the degradation of extracellular matrix through the action of metalloproteinases [38]. 


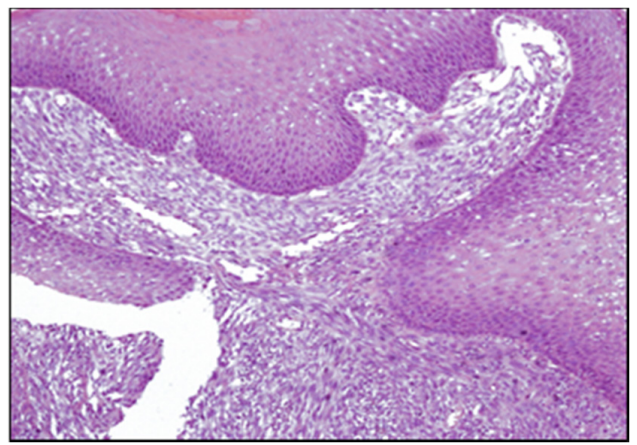

(A)

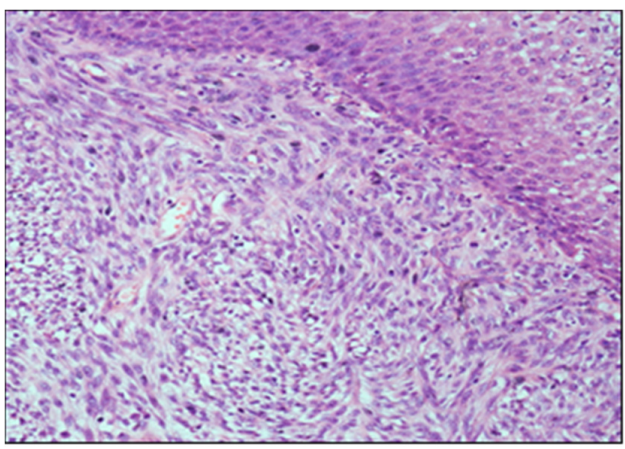

(B)

Figure 3. Photomicrograph of oral amelanotic melanoma ((A), Objective $10 \times$; (B), Objective $20 \times)$. Hematoxylin and eosin.

The histopathological diagnosis of melanoma may be difficult if the tumor does not contain melanin. Amelanotic malignant melanomas may represent one third of all melanoma cases in dogs.

Their histopathological aspect may resemble carcinomas, sarcomas, lymphomas, and osteogenic tumors. For this reason, the diagnosis of malignant melanoma should be made with the use of immunohistochemistry $[11,39,40]$. Teixeira et al. [13] used two different antibodies to confirm the diagnosis of malignant melanoma in amelanotic cases: HMB 45 (Mouse monoclonal anti-human HMB45, from Dako) and Melan A (Monoclonal mouse anti-human Melan-A, from Dako), and both were considered suitable to immunostain canine melanocytes. Ramos-Vara et al. [11] considered Melan A as a specific and sensitive marker for malignant melanomas. Smedley et al. [41] evaluated 49 amelanotic melanomas and created a cost-effective and efficient immunodiagnostic cocktail panel containing antibodies against PNL2, Melan-A, TRP-1, and TRP-2 that had 100\% specificity and $93.9 \%$ sensitivity in identifying canine oral amelanotic melanocytic neoplasms. In addition, malignant melanomas are positive for vimentin and variably positive for S-100 protein and neuron-specific enolase (NSE) [42].

In order to use immunohistochemical techniques to study melanoma cell characteristics, it is frequently necessary to remove melanin from the histopathological specimen. There are several methods to do bleaching in melanoma cells, but the one described by Silva et al. [43] is one of the most effective, in which slides were immersed only in $10 \%$ hydrogen peroxide in $\mathrm{pH} 7.40 .2 \mathrm{~mol} / \mathrm{L}$ Tris- $\mathrm{HCl}$ buffer solution for $24 \mathrm{~h}$ in the dark at room temperature.

\section{Canine Melanoma: Molecular Aspects}

Melanomas in humans seem to arise from normal melanocytes that suffer a number of molecular events that lead to their transformation. The progression from normal melanocytes to melanoma sometimes involves its transformation to melanocytic nevus. The genetic alterations involved in this progression are still under study. Several genes/genetic pathways were identified in human melanomas, and these are important for the diagnosis, establishment of prognosis, and drug targeting [44]. Some of these genes are described below:

- CDKN2A Locus-about 70\% of melanomas harbor mutations or deletions in this locus on chromosome 9p21.

- Genes that are altered when normal melanocytes generate a nevus: BRAF, NRAS, and INK4a/ARF.

- Genes that are mutated or deregulated when a nevus is transformed to a melanoma: BRAF, NRAS, INK4a/ARF, PTEN, c-kit, NEDD9, and MITF.

Genetic alterations in canine malignant melanomas from mucosal or acral sites have not been fully described. Activating mutations in BRAF exon 15 have not been found [6,45]. Activating mutations 
of NRAS and c-kit appear to be absent in canine mucosal melanoma, in contrast to human mucosal melanoma, where these genes are mutated in $15 \%$ of tumors $[44,46,47]$. Further studies are necessary to understand the molecular basis of canine malignant melanomas.

Genetic alterations in canine malignant melanomas from human mucosal melanomas have not been fully studied (Table 2). Mutations in exon 15 of BRAF are not found [6], similar to human mucosal malignant melanoma [48]. Activating mutations of NRAS are presented in three of 77 cases [19] and c-kit appears absent in canine mucosal melanomas [49], in contrast to human mucosal melanoma, where these genes are mutated in $4 \%$ and $14 \%$ of tumors, respectively [50].

Table 2. Genes altered by mutations in canine and human mucosal malignant melanomas.

\begin{tabular}{ccc}
\hline & Human & Dog \\
\hline BRAF & $4 \%[50], 2 \%[48], 6 \%[14]$ & $0 \%[6,19]$ \\
C-KIT & $12.5 \%[16], 4 \%[50]$ & $0 \%[49]$ \\
NRAS & $22 \%[15], 14 \%[50], 10 \%[14]$ & $6 \%[19]$ \\
PTEN & $48.1 \%[15]$ & $4 \%[19]$ \\
GNAQ & $0 \%[16]$ & $0 \%[19]$ \\
CDK4 & $0 \%[17]$ & $0 \%[19]$ \\
\hline
\end{tabular}

In 2014, Gillard et al. [19] compared the histopathology and genetic alterations of canine and human melanomas. They observed that dog malignant melanomas present cytological characteristics similar to human melanoma simulating "nevus" and "animal type," suggesting a new melanoma classification. They also studied six genes in canine melanomas that are recurrent mutations in human melanomas, BRAF, NRAS, PTEN, KIT, GNAQ, and CDK4. In total, out of the 95 cases (77 oral and 18 cutaneous melanomas), no mutations were found in BRAF, KIT, GNAQ, and CDK4 genes; only three had a positive NRAS mutation and two had a PTEN gene mutation, of which one case had both changes [19]. BRAF mutations were seen in 57\% of human cutaneous melanomas and NRAS was mutated in $17 \%$ of samples. Both changes were seen in $15.4 \%$ [51].

The low frequency of BRAF mutations associated with UV-independent carcinogenesis and oral anatomical distribution of canine melanomas supports the dog as a spontaneous model for investigation of non-UV-associated human melanomas [52].

Human and canine melanoma share differential gene expression patterns of MAPK, but similar sensitivity in cell culture to therapeutic inhibitors of MAPK (AZD6244) and PI3K/AKT (rapamycin) [6].

Dog malignant melanomas share numerous immunohistochemistry similarities (KIT, PTEN, and phosphorylated forms of AKT and ERK1/2) with human melanoma subtypes; particularly with mucosal, digital and ungual localizations that usually show high growth and aggressive behavior [5].

\section{Canine Oral Melanomas}

Melanoma is considered the most common oral malignancy in dogs [53], accounting for $14.4 \%$ to $45.5 \%$ of all oral tumors [54-59]. Some studies describe melanomas as the second most frequent oral cancer in dogs [54,56]. Oral malignant melanoma may also occur in cats and humans, but it is infrequent $[60,61]$.

Malignant melanoma can be located in any portion of the oral cavity, but the gingival mucosa is the most common site [54,62]. The mandibular labial mucosa was the most common area, affected in $53 \%$ of cases, as described by Ramos-Vara et al. [11]. Although malignant melanoma rarely affects the tongue, it is considered the most common tumor type of this anatomic site as described by Dennis et al. [63], and large-breed dogs, particularly Chow Chow and Shar Pei, are at increased risk for malignant lingual melanoma [62,63].

Small-breed dogs and dogs with pigmented oral mucosa appear to be at increased risk for the development of oral malignant melanoma [61,62]. Cocker Spaniel, Poodle, Pekinese, Gordon Setter, Chow Chow, Golden Retriever, mixed-breed dogs, and Dachshund are the most commonly affected 
breeds $[11,61]$. Boxers and German Shepherds appear to be less affected by the disease, as described by Ramos-Vara et al. [11].

Dogs with oral malignant melanoma are usually 10.5 to 12 years old, with an average age of 11.4 years $[11,54,61]$. Males are supposed to be more predisposed to oral malignant melanomas, as verified by Todoroff et al. [54] and Vos et al. [55]; however, Ramos-Vara et al. [11], in a study of 328 dogs diagnosed with oral melanoma, and Teixeira et al. [13] found no such predisposition.

Oral malignant melanoma is a highly locally aggressive disease, with local invasion into bones occurring in $57 \%$ of lesions, with metastasis to regional lymph nodes (Figure 4 ) in $30.3 \%$ to $74 \%$ of cases, and to the lungs and other distant organs in $14 \%$ to $92 \%$ of affected dogs $[11,61,64]$.

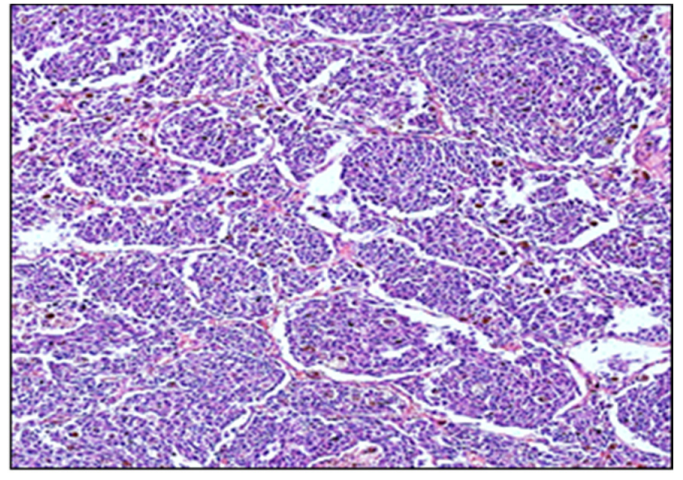

(A)

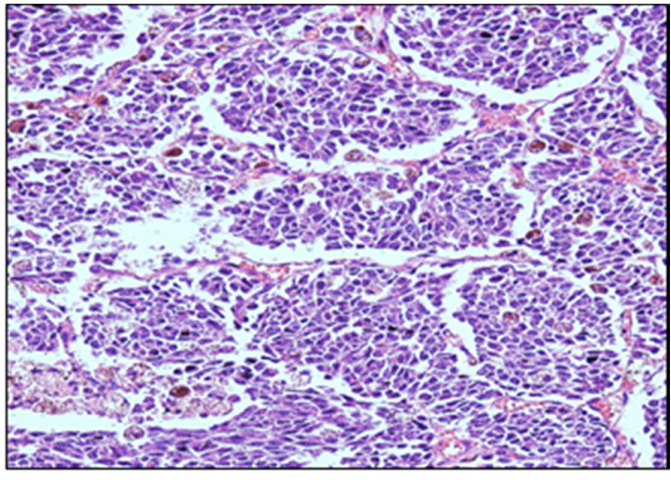

(B)

Figure 4. Photomicrograph of lymph node metastasis from oral melanocytic neoplasm ((A), Objective $10 \times$; (B), Objective $20 \times$ ). Hematoxylin and eosin.

Melanoma is one of the few neoplasms in animals for which location is an important prognostic indicator [65]. The statement that all oral melanocytic neoplasms should be considered malignant is commonly found throughout the literature and has become dogma [41].

The prognosis for oral melanoma varies from favorable to unfavorable, with an overall median survival time (MST) of less than 36 months, depending on the intrinsic characteristics of the tumor, and the stage of the disease [61,66-69].

Historically, many studies confirm that oral and lip melanomas have a poorer prognosis when compared to skin melanomas. The differences concerning the results of different studies of lip melanomas are directly related to the real site of the tumor, that is, either in the skin or in the mucocutaneous junction. In one study, oral melanomas had an MST of 147 days, while the MST of melanoma of the lips and digits were 676 days and 725 days, respectively [18]. Large and poorly or non-pigmented tumors, necrosis, ulceration, high rate of cell proliferation (PCNA expression), and p53 expression are considered poor prognostic factors [29]. Amelanotic melanomas showed a significantly higher amount of mitotic cells when compared to melanotic melanomas [24]. The PCNA (proliferating cell nuclear antigen) in pigmented and non-pigmented melanomas was also assessed. It was demonstrated that cells of all samples stained positive for PCNA, confirming the proliferative activity of this tumor.

The World Health Organization (WHO) staging scheme for dogs with oral melanoma is based on the size of the tumor and the presence of regional and distant metastasis (Table 3) [70]. These staging systems are old and size is not considered a prognostic factor for malignant melanoma $[18,28,36]$, but they are still cited in veterinary practice.

Dogs with stage I melanomas have tumors smaller than $2 \mathrm{~cm}$ in diameter, while dogs with stage II and III have tumors measuring between 2 to $4 \mathrm{~cm}$, and more than $4 \mathrm{~cm}$, respectively. Dogs with lymph node metastasis are also classified as stage III disease, and dogs with distant metastasis are classified as stage IV disease. Median survival times for dogs with oral melanoma treated with surgery are approximately 17-18 months, 5-6 months, and 3 months for stage I, II, and III disease, respectively [67]. 
Table 3. TNM classification of tumors in domestic animals, WHO, Geneva, 1980.

\begin{tabular}{|c|c|c|c|}
\hline \multicolumn{4}{|c|}{ Clinical Staging System for Oral Tumor } \\
\hline \multicolumn{4}{|c|}{ Primary Tumor (T) } \\
\hline & & \multicolumn{2}{|c|}{ Tumor in situ } \\
\hline & & \multicolumn{2}{|c|}{ Tumor $<2 \mathrm{~cm}$ in diameter at greatest dimension } \\
\hline & & \multicolumn{2}{|c|}{ Without evidence of bone invasion } \\
\hline & & \multicolumn{2}{|c|}{ With evidence of bone invasion } \\
\hline & & \multicolumn{2}{|c|}{ Tumor $2-4 \mathrm{~cm}$ in diameter at greatest dimension } \\
\hline & & \multicolumn{2}{|c|}{ Without evidence of bone invasion } \\
\hline & & \multicolumn{2}{|c|}{ With evidence of bone invasion } \\
\hline & & \multicolumn{2}{|c|}{ Tumor $>4 \mathrm{~cm}$ in diameter at greatest dimension } \\
\hline & & \multicolumn{2}{|c|}{ Without evidence of bone invasion } \\
\hline & & \multicolumn{2}{|c|}{ With evidence of bone invasion } \\
\hline \multicolumn{4}{|c|}{ Regional Lymph Nodes (N) } \\
\hline & & \multicolumn{2}{|c|}{ No regional lymph node metastasis } \\
\hline & & \multicolumn{2}{|c|}{ Movable ipsilateral lymph nodes } \\
\hline & & \multicolumn{2}{|c|}{ No evidence of lymph mode metastasis } \\
\hline & & \multicolumn{2}{|c|}{ Evidence of lymph mode metastasis } \\
\hline & & \multicolumn{2}{|c|}{ Movable contralateral lymph nodes } \\
\hline & & \multicolumn{2}{|c|}{ No evidence of lymph mode metastasis } \\
\hline & & \multicolumn{2}{|c|}{ Evidence of lymph mode metastasis } \\
\hline \multicolumn{2}{|c|}{ N3 } & \multicolumn{2}{|c|}{ Fixed lymph nodes } \\
\hline \multicolumn{4}{|c|}{ Metastasis (M) } \\
\hline \multirow{2}{*}{\multicolumn{2}{|c|}{$\begin{array}{l}\text { M0 } \\
\text { M1 }\end{array}$}} & \multirow{2}{*}{\multicolumn{2}{|c|}{$\begin{array}{l}\text { No distance metastasis } \\
\text { Distance metastasis }\end{array}$}} \\
\hline & & & \\
\hline Stage Group & Tumor (T) & Nodes (N) & Metastasis (M) \\
\hline I & $\mathrm{T} 1$ & N0, N1a, N2a & M0 \\
\hline II & $\mathrm{T} 2$ & N0, N1a, N2a & M0 \\
\hline \multirow{2}{*}{ III } & T3 & N0, N1a, N2a & M0 \\
\hline & Any $\mathrm{T}$ & $\mathrm{N} 1 \mathrm{~b}$ & M0 \\
\hline \multirow[b]{2}{*}{ IV } & Any $\mathrm{T}$ & $\mathrm{N} 2 \mathrm{~b}, \mathrm{~N} 3$ & M0 \\
\hline & Any $\mathrm{T}$ & Any N & M0 \\
\hline
\end{tabular}

In a study of 70 dogs with oral melanoma, Tuohy et al. [71] observed that $11.4 \%$ of dogs had mandibular lymph node metastasis and $1.4 \%$ of dogs had lung metastasis at the time of diagnosis. After 821 days (mean time of follow-up), 8.6\% of mandibular lymph node metastasis, $17.1 \%$ of lung metastasis, $5.7 \%$ of metastasis to both sites, and $4.2 \%$ of metastasis to lung and other locations were observed. Williams et al. [64] reported that $70 \%$ of canines with melanomas had metastasis when lymphadenomegaly was present, and that $40 \%$ had metastasis in the absence of lymphadenomegaly. Harvey et al. [72] observed that dogs with untreated oral melanomas have a median survival time of 65 days.

Gillard et al. [19] performed clinical and histopathological analyses of 153 malignant canine melanomas with a four-year follow-up. These samples were histopathological characterization by human classification and showed that most canine tumors are intradermal and homologous to human nevocytoid $(72 \%)$ type, animal type $(16.5 \%)$, composite type $(6.5 \%)$, pleomorphic type $(4.5 \%)$, and superficial spreading melanoma type (0.5\%) [19]. Figure 5 shows a representative histology of canine oral malignant melanoma on which local invasion, sparsely pigmented cells, and pleomorphism with variation in shape and cell or nuclear size can be seen.

A recent study of over 382 canine oral melanomas did not find statistically significant differences in survival among different sites or mitotic indices [11]. 


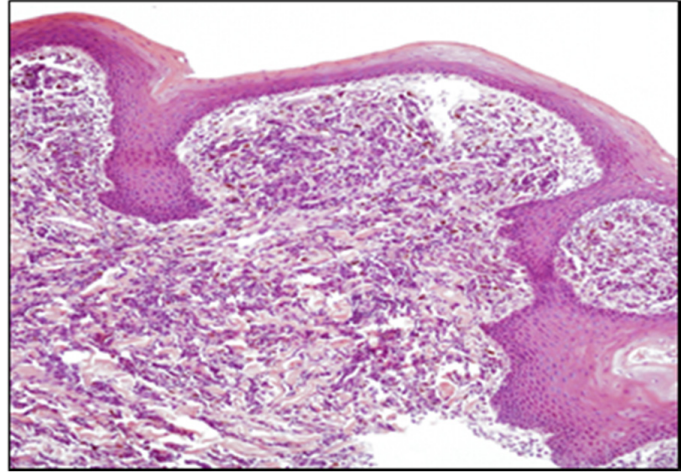

(A)

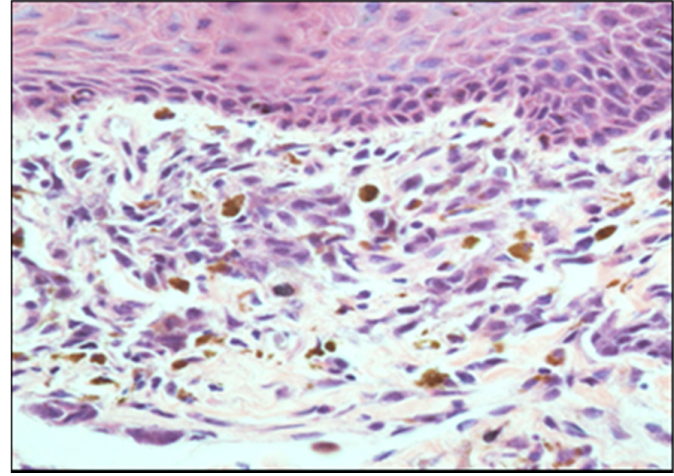

(B)

Figure 5. Photomicrograph of oral melanocytic neoplasm ((A), Objective $4 \times$; (B), Objective $40 \times)$; Hematoxylin and Eosin.

\section{Canine Ocular Melanomas}

Ocular melanocytic tumors, benign or malignant, may occur in humans and domestic animals. These tumors may affect the eyelids, conjunctiva, orbit, limbo, and uvea [73,74]. Melanomas have different biological behaviors depending on the location in the eye [75]. In general, canine ocular melanomas are less aggressive than oral melanomas. Within the ocular melanoma group, the uveal melanoma is characterized by being more aggressive than the epibulbar melanoma [75].

Eyelid tumors in dogs are usually benign, such as sebaceous adenomas and sebaceous epitheliomas. Among all eyelid tumors, the melanocytic neoplasms account for $20 \%$, and only $8 \%$ of these are melanomas [73]. Most, if not all, eyelid skin melanomas are benign [75]. Eyelid melanomas in dogs are usually pedunculated with nodular internal infiltration [73]. They are generally non-aggressive tumors, but occasionally some pigmented melanomas act aggressively and become locally invasive with the development of metastasis [73]. When compared to dogs, melanomas of the eyelid in humans carry a worse prognosis, especially when the tumor is located on the lid margin [76].

Conjunctival melanomas generally affect the nictitating membrane and the bulbar and/or eyelid conjunctiva [77]. Rottweilers and Cockers Spaniels are predisposed [74]. Lesions appear as dark, raised solid masses. Metastasis is rarely seen, but when it occurs it is typically associated with melanomas of the conjunctival eyelid. Complete surgical removal is warranted in early-diagnosed cases [77]. Due to the high risk of local recurrence, enucleation should be considered for invasive tumors [74]. Although conjunctival melanomas in humans are unusual, they have the potential to cause vision impairment and reduce life expectancy, with a mortality rate varying from $18 \%$ to $44 \%[74,78]$.

Canine and feline limbal melanomas have a benign biological behavior. They appear as raised, well-circumscribed heavily pigmented masses that arise from scleral and subconjunctival connective tissue melanocytes. Most of them develop slowly and are located closely to the superior aspect of the limbus. Labrador Retrievers are genetically predisposed [79].

Among the intraocular melanocytic tumors in the dog, melanocytomas are the most common tumors encountered, representing approximately $80 \%$ of the neoplasms. Melanomas account for only $20 \%$ of tumors [74]. It is difficult and unreliable to clinically differentiate between melanocytomas and melanomas, since melanocytomas can be locally aggressive and even invade the drainage angle and adjacent tissues $[73,80]$. Therefore, histopathological analysis is indispensable for a definitive diagnosis [81]. Despite the fact that melanocytomas are benign, when located in the iris, they can spontaneously cause necrosis and pigment dispersion, which may lead to obstruction of drainage and cause glaucoma in dogs and humans [82] (Figure 6). 


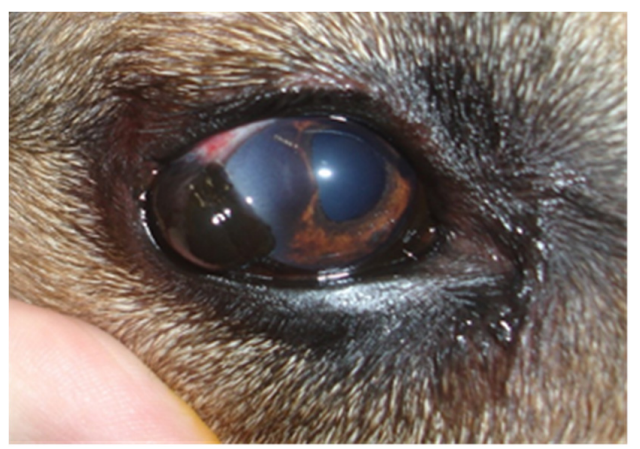

(A)

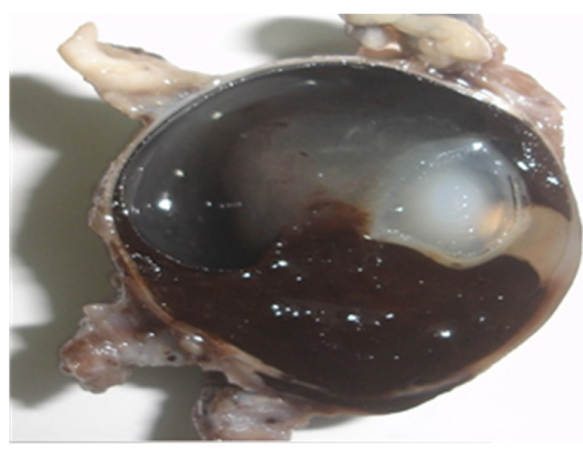

(B)

Figure 6. Photographs showing: blackened mass in the iris with extraocular extension (A) and sagittal section of the eyeball revealing melanocytic neoplasia of iris, ciliary body, and choroid (B) (Eduardo Perlmann).

Melanocytomas most commonly affect the anterior uvea in dogs, but rarely affect the choroid [29]. When located in the uvea, they may cause several changes, such as intraocular hemorrhage, uveitis, and secondary glaucoma. Despite the fact that human intraocular melanocytomas are commonly located at the level of the optical disk or adjacent tissues, this location was never described in dogs [74]. An early diagnosis and rapid surgical treatment increase the chances of a favorable prognosis [83]. Wilcock et al. [75] studied 91 canine uveal melanocytic neoplasms, and only three developed metastatic disease. These data emphasize the low metastatic rate of uveal melanoma in dogs. Giuliano et al. [84], however, showed that animals affected by uveal melanomas had a lower life expectancy when compared with patients diagnosed with uveal melanocytomas. Tumors located in the uvea most frequently are consistent with primary neoplasia; however, animals presenting with intraocular-pigmented tumors should have a complete diagnostic work-up and physical exam to rule out metastasis [85].

In general, when tumors are only confined to the intraocular space, the recommended treatment is enucleation. Exenteration is indicated when the tumor extends to the extraocular space [83]. Other treatment options include iridectomy or diode laser photocoagulation in small-pigmented tumors of the iris [86]. There is no evidence that chemotherapy is effective in the treatment of ocular melanomas [87], but long-term follow-up evaluation would be needed. Ocular malignant melanoma had significantly shorter survival time than benign melanocytomas [84].

\section{Canine Digital Melanomas}

Melanoma is considered the second most common type of cancer of the digits in dogs $[22,29,88]$. Local invasion is a common feature of digital melanomas and $5 \%-58 \%$ of dogs with this disease have evidence of bone lysis [22,88-90]. Tumors of the footpad and interdigital region are less likely to invade into the bone $[22,90]$. Besides possible local invasion, regional and distant metastasis via lymphatics is frequently noted. It is estimated that $30 \%-40 \%$ of dogs have metastasis at the time of presentation and that even after appropriate local treatment with surgery, subsequent metastasis is frequently seen $[22,88]$.

Due to its aggressive behavior, canine digital melanomas often require digital amputation. The median survival time for dogs without metastasis at the time of diagnosis treated with digital amputation is approximately 12 months, with $42 \%-57 \%$ of dogs surviving one year, and $11 \%-13 \%$ surviving two years $[22,88,90,91]$.

\section{Canine Cutaneous Melanomas}

In contrast to digital melanomas, cutaneous melanomas typically have benign behavior in dogs, with the exception of melanomas that develop on the mucocutaneous junctions $[18,92]$. They account 
for $0.8 \%-2 \%$ of all canine cutaneous tumors [64] and are more commonly seen in dogs with heavily pigmented skin. Predisposed breeds include Scottish Terrier, Poodle, Golden Retriever, Dachshund, Cocker Spaniel, Miniature Poodle, Chow Chow, and Gordon Setter [93]. Benign skin melanomas are usually solitary, small, pigmented, firm, and freely moveable over deeper structures. Malignant melanomas tend to be fast-growing tumors, and often are ulcerated, and pigmented (grey, brown, or black) [21].

The most common sites for benign cutaneous melanomas are the face (near the eyelids), trunk, and extremities. Malignant melanoma is found most frequently on the head, ventral abdomen, and scrotum. When metastases occur, lymph nodes, followed by lungs, are the main organs involved [29].

Brockley et al. [94] studied 63 dogs diagnosed with melanomas at different locations. Surgery was performed in 24 cutaneous melanomas, with $88 \%$ of dogs alive a year after treatment.

Most dogs are cured with complete surgical excision, although some characteristics of the tumor, such as a mitotic index of $\geqslant 3 / 10 \mathrm{HPF}$, the presence of $\geqslant 20 \%$ of nuclear atypia, a Ki67 index $\geqslant 15 \%$, ulceration, lymphatic invasion, and tumors extending beyond dermis, may have a negative influence on prognosis $[18,41,92]$.

\section{Treatment Modalities for Canine Melanomas}

\subsection{Surgery}

Surgery is the most common and main treatment option for local management of all melanomas, including oral [69], ocular [74], cutaneous, and digital melanomas [90,92]. Due to its high metastatic potential, systemic therapy should also be considered [61,62].

Tuohy et al. [71] studied 70 cases of canine oral malignant melanomas treated with curative intent surgery. Surgical resections were done with wide margins, including 2 to $3 \mathrm{~cm}$ of bone margins, and $1 \mathrm{~cm}$ of soft tissue margins. Histopathological analysis showed that $72.9 \%$ of tumors were completely excised, with $10 \%$ of these patients developing local tumor recurrence. In this study, dogs that had surgery as their sole treatment option had a progression-free interval (PFI) longer than 567 days, and an MST of 874 days. In a survey performed by Boston et al. [69], among wide-margin surgeries performed, $79.3 \%$ (73/92) were completely excised based on histologic evaluation, and the recurrence rate was $8.3 \%(6 / 73)$ in this group. The MST of these dogs was 354 days. Esplin [65] studied 61 dogs diagnosed with well-differentiated oral melanomas that were surgically excised, and reported an MST of 34 months with $3.2 \%$ of local recurrence.

Regional lymph node resection has been studied in maxillofacial tumors. The analysis of sentinel lymph nodes provides essential information regarding the clinical stage of disease, and also helps determine the appropriate treatment plan [95,96]. As previously shown, in a survey of 100 dogs with oral malignant melanoma, 53\% had cytological or histopathological evidence of mandibular lymph node metastasis, even in normal sized nodes [64]. Therefore, regional lymph node removal is warranted, especially in dogs with oral melanomas.

\subsection{Radiation Therapy}

Radiation therapy is effective for malignant melanomas in dogs and may be useful for the control of local disease and involved regional lymph nodes [97]. Response rates are generally best for smaller tumors rather than for salvage therapy against large tumor burdens late in their clinical progression [98]. Another prognostic factor that appears to affect therapy outcome includes the presence of bone lysis. Proulx et al. [97] found that dogs without evidence of radiologic bone destruction experienced longer disease-free intervals and overall survival when compared to dogs with bone invasion.

Although melanoma has traditionally been viewed as a "radio-insensitive" disease, many studies suggest a significant role for radiation therapy in the treatment of melanoma [99]. Optimal fractionation schedules have not yet been established for canine malignant melanoma; however, hypofractionated protocols have been utilized with some success [93]. Overall response rates range from $82 \%$ to 
$94.4 \%$, with the complete and partial resolution of tumors in $51 \%$ to $69 \%$ and $25 \%$ to $31 \%$ of cases, respectively [91-102]. The reported median time to progression ranges from 3.6 to 7.9 months with a median survival time varying from 5.3 to 11.9 months [97,98,100-103].

Chemotherapy alone has generally offered little benefit in terms of clinical outcome for the control of local canine melanomas; however, a few published studies have shown that the association of radiation with chemotherapy may potentially slow local progression and/or improve overall survival. Cancedda et al. [102] compared the efficacy of radiation therapy ( $5 \times 6 \mathrm{~Gy}$ ) alone and radiation therapy with post-radiation temozolamide $\left(60 \mathrm{mg} / \mathrm{m}^{2}\right.$ PO for five consecutive days every 28 days $)$ in dogs with measurable malignant melanoma. Dogs treated with temozolamide had a significantly longer median time to progression (6.8 months) than dogs treated only with radiation (3.6 months). Freeman et al. [103] retrospectively looked at dogs with incompletely resected oral melanoma treated with either cisplatin (10-30 mg $\left./ \mathrm{m}^{2} \mathrm{IV}\right)$ or carboplatin $\left(90 \mathrm{mg} / \mathrm{m}^{2} \mathrm{IV}\right)$ given once weekly $1 \mathrm{~h}$ before receiving radiation therapy $(6 \times 6 \mathrm{~Gy})$. The reported median survival time was 11.9 months, representing the longest survival time when compared to the survival time previously reported for dogs with incompletely resected oral malignant melanoma [103]. Other studies combining radiation with chemotherapy agents, such as carboplatin, cisplatin, or melphalan, did not have a significant impact on either time to progression or overall survival $[97,101,104]$.

\subsection{Chemotherapy}

Despite treating dogs with appropriate local therapies, such as surgery and/or radiation therapy, the ultimate cause of death, especially in oral melanomas, is metastasis. Therefore, the use of systemic therapies is typically recommended. Many chemotherapy protocols have been published in the veterinary literature with minimal improvement in survival times when compared to local treatment alone.

Many chemotherapy protocols using platinum agents have been studied. Rassnick et al. [104] reported an overall response rate of $28 \%$ using carboplatin as a single agent (300 to $350 \mathrm{mg} / \mathrm{m}^{2} / \mathrm{IV} /$ every 21 days) prior to surgery in dogs with oral (25/27) and cutaneous melanomas (2/27). Boria et al. [105] reported an overall response rate of $18 \%$ and a MST of 119 days using cisplatin (50 to $55 \mathrm{mg} / \mathrm{m}^{2} / \mathrm{IV} /$ every three weeks) in combination with piroxicam $(0.3 \mathrm{mg} / \mathrm{kg} / \mathrm{PO} / 24 \mathrm{hs})$ in oral melanomas.

Brockley et al. 2013 [94] evaluated the effect of carboplatin on the survival of 63 canine patients diagnosed with oral, cutaneous, or digital malignant melanomas. In this survey, carboplatin was administered at $300 \mathrm{mg} / \mathrm{m}^{2}$ IV every 21 days for a total of $4-6$ cycles. The addition of carboplatin after local therapy did not lead to a significant increase in survival times, and the anatomic site was significantly associated with survival. The overall median survival time for patients with oral, digital, and cutaneous melanomas were 389 days, 1350 days, with a median follow-up of 776 days, respectively.

In another survey, Dank et al. [106] compared the outcome of 17 dogs treated with surgery, adjuvant carboplatin (150 to $300 \mathrm{mg} / \mathrm{m}^{2} / \mathrm{IV}$ every three weeks), with or without radiation therapy. The MST was 387 days for the group treated with radiotherapy and 440 days for the group without the addition of radiotherapy.

In a comparative study reported by Tuohy et al. [71], surgery with or without any adjuvant therapy (carboplatin, cyclophosphamide as a metronomic therapy, radiotherapy, or xenogeneic canine melanoma vaccine) did not improve overall survival time in dogs with oral melanoma. The MST reported was 874 and 396 days for dogs that had surgery or surgery plus adjuvant therapy, respectively. Boston et al. [69] treated 151 dogs with oral melanoma and also concluded that there were no benefits in survival times among dogs that had surgery alone (MST of 335 days for 98 dogs) versus dogs that had surgery followed by systemic adjuvant therapy (MST of 352 for 53 dogs). Carboplatin, lomustine, dacarbazine, doxorubicin, metronomic chemotherapy, or commercial melanoma vaccine were the adjuvant therapies used in this study. Postoperative radiation therapy was associated with a longer survival time (MST of 1747 days), but was not significant in the multivariate analysis of this study. 


\subsection{Immunotherapy}

Many researchers are currently using and developing therapies to activate the immune system of dogs. The immune responses by therapeutic vaccine represent a potential and powerful strategy for the treatment of melanomas [107]. There is wide evidence that the immune system could modulate the progression and metastasis of melanoma.

Many biological agents have the capacity to demonstrate antitumor activation, such as BCG, IFN-alpha, IL-2, and immunization activators, using an anticancer vaccine [108].

Bacillus Calmette-Guérin (BCG) is used intralesionally in melanomas to activate an immune response and induce tumor regression; however, there may be some complications, such as granulomas and hypersensitivity reactions [109].

Corynebacterium parvum is a bacterial substance that has antitumor activity in humans and canines with melanoma. MacEwen et al. [67] used C. paroum in dogs with stage II and III oral melanomas and compared the outcomes between surgical excision alone and surgery plus C. parvum immunotherapy. Animals who received C. parvum and surgery had a better prognosis than those with surgery only.

In rodents, dogs, and men, a liposome-encapsulad muramyl tripeptide phosphatidyl ethanolamine (L-MTP-PE), when used in vivo, actives monocytes and macrophages, resulting in antitumor activity, which can lead to melanoma metastasis tumor regression or at least stable disease. According to MacEwen et al. [108], when L-MTP-PE was used alone or in combination with GM-CSF the antitumor response was minimal, and only prolonged the survival time in dogs with stage I melanoma.

Bianco et al. [110], demonstrated that peripheral blood mononuclear cells with apoptotic melanoma cells significantly increased the antitumor immune response, leading to a reduction of the melanoma in three out of five dogs treated intralesionally with FasL-DNA.

Alexander et al. [111] used an allogeneic melanoma vaccine in combination with human a glycoprotein 100 (hgp 100), which is a xenogeneic melanoma protein. The vaccine was well tolerated in dogs, and the tumor response rate was 35\% for six weeks (including complete response and stable disease).

Hogge et al. [112] used an autologous vaccine made of lysate cells transfected with GM-CSF in dogs with soft tissue sarcoma or melanoma. There was a large concentration of inflammatory cells at the site of vaccine administration, different from the ones that received a vaccine placebo only.

A xenogeneic human DNA-encoding tyrosinase protein vaccine (Oncept ${ }^{\circledR}$ ) has been developed and used in dogs with stage II and III oral malignant melanoma [113]. This vaccine was generally well tolerated in a study of 111 dogs. No systemic reactions occurred, only local hematomas and pain at the injection site [114]. In another retrospective study, medical records from 45 dogs were reviewed, including 30 dogs with stage II and III disease, treated with the Oncept ${ }^{\circledR}$ vaccine after appropriate achievement of loco-regional cancer control. The review found that dogs that received the vaccine did not achieve a greater progression-free survival, disease-free interval, or median survival time than dogs that did not receive the vaccine [115].

The role of dendritic cells (DCs) as a biological adjuvant against malignant melanoma through the induction of an active immune response in the oncologic patient has been explored. Dendritic cells, as professional antigen-presenting cells with an ability to initiate the immune response, could therefore qualify for vaccination strategies to treat human or canine cancers. Compared with the human clinical trials using DC-based vaccines, reports of testing in dogs are scarce.

For humans, at least 13 clinical trials conducted in the United States have been registered using ex vivo autologous DCs [116] and, for dogs, only a few reports have been published to strengthen the rational use of DC vaccination for canine malignant melanoma $[117,118]$. Both protocols used bone marrow-derived DC of dogs with or without malignant melanoma. Gyorffy et al. [117] conducted a study using a few canine melanoma bearers and employed DC transduced with an adenovirus vector encoding a xenoantigen, human melanoma antigen gp100, as a coadjuvant of radiation therapy. One dog had an antigen-specific cytotoxic T lymphocyte (CTL) activity in peripheral blood lymphocytes, with no clinical signs, either locally or systemically, with melanoma recurrence 48 months 
after initial DC injection. However, another dog, which had a negative CTL activity, relapsed 22 months after vaccination. Tamura et al. [118], using an autologous DC pulsed with canine melanoma CMM2 cell lysate, efficiently elicited T cell-mediated immunity against CMM-2 cells in vivo, reinforcing the rationale to use DC as a therapeutic vaccine.

Although the immunotherapeutic approach using a DC vaccine to drive tumor-specific immune responses appears to be a promising strategy to control malignant melanoma, there are limitations, such as the cost of vaccine production for veterinary use as well as the very fragmentary designed strategies available.

\subsection{Outcomes after Treatment}

Table 4 describes the reported outcomes for canine oral malignant melanoma treated with different protocols.

Table 4. Outcomes for canine oral malignant melanoma after different therapeutic protocols.

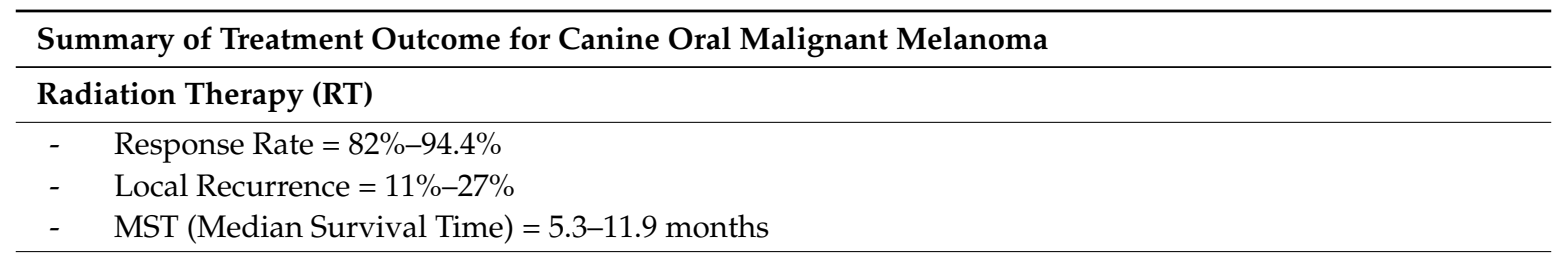

\section{References:}

Theon et al., 1997 (98); Bateman et al., 1994 (100); Murphy et al., 2005 (101); Cancedda et al., 2014 (102);

Proulx et al., 2003 (97); Freeman et al., 2003 (103).

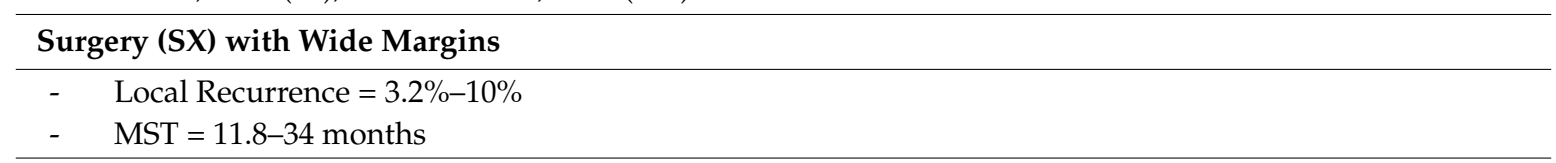

References:

Tuohy et al., 2014 (71); Boston et al., 2014 (69); Esplin et al., 2008 (65).

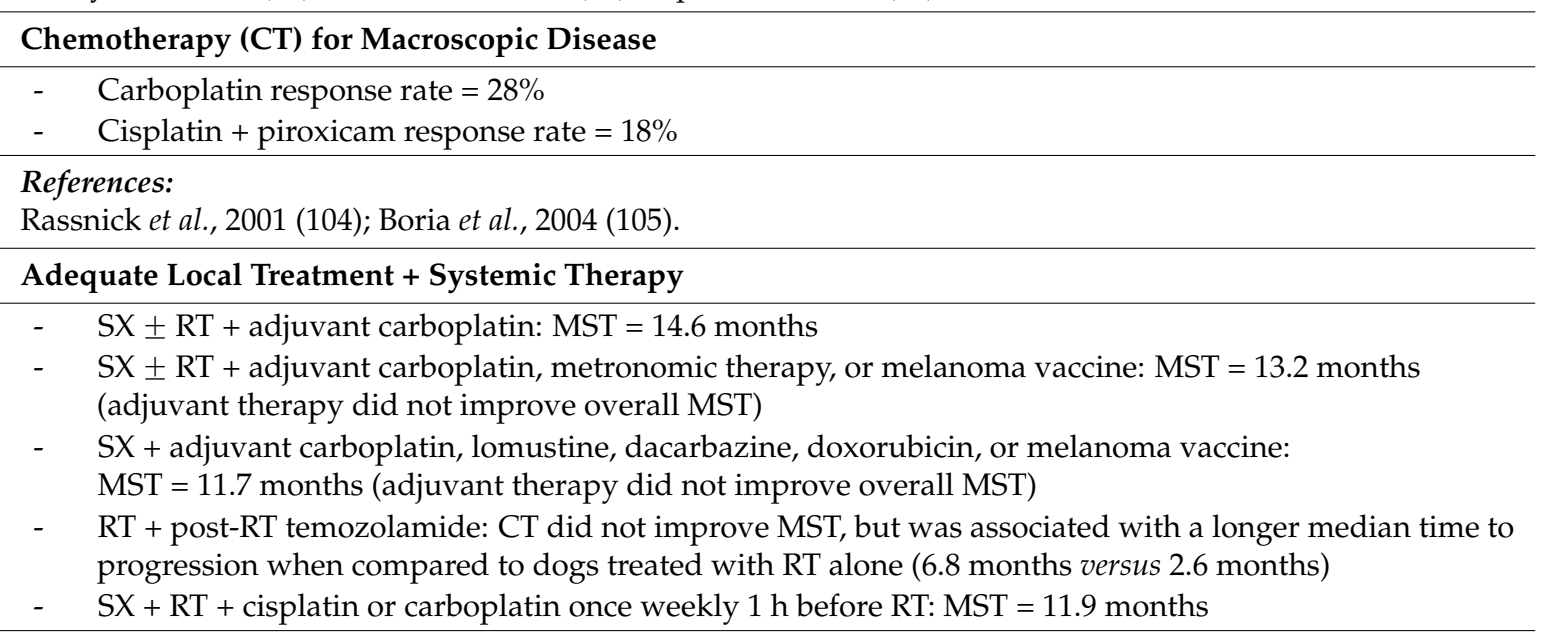

\section{References:}

Dank et al., 2012 (106); Tuohy et al., 2014 (71); Boston et al., 2014 (69);

Cancedda et al., 2014 (102); Freeman et al., 2003 (103).

$$
\text { Abbreviations: } \mathrm{RT} \text { = radiotherapy, } \mathrm{SX}=\text { surgery, } \mathrm{CT} \text { = chemotherapy, } \mathrm{MST} \text { = median survival time. }
$$

\subsection{New Perspectives for the Treatment of Canine Melanomas}

The aggressive nature of melanomas in canines and humans, with short survival times and minimal clinical outcome benefits after surgery and adjuvant therapy, emphasizes the importance of new studies to find an effective therapy for treatment and prevention of melanomas metastasis. 
A canine therapeutic vaccine has been commercially available since 2007. The Merial melanoma vaccine for dogs $\left(\right.$ Oncept $\left.^{\circledR}\right)$ consists of DNA encoding the gene for the human melanocyte protein tyrosinase but apparently seems not to cure all melanoma cases. Published studies evaluating the survival times in dogs with melanoma in the mouth undergoing surgery and treatment with the Merial melanoma vaccine report average survival times of 599 days $(20$ months) or longer $[113,114]$. These results, though not from randomized studies, are promising and have prompted many veterinary oncologists to recommend the vaccine for patients with stage II and III melanoma despite the lack of FDA-standard clinical trials. The vaccine is well tolerated and has not been reported to be associated with side effects requiring medical intervention. In patients with very large and aggressive melanoma, there may not be sufficient time for an immune response to be mounted against the tyrosinase protein to prevent progression of the melanoma. In fact, $15 \%$ of patients treated with the vaccine reportedly die within three months of initiation of treatment, presumably due to the aggressive nature of the melanoma and insufficient time for the vaccine to be effective [119].

Lupeol [120] is among the new therapies under study. Lupeol is a triterpene extracted from various fruits and vegetables that reportedly inhibits melanoma cell proliferation in vitro and in vivo. A total of 11 dogs bearing buccal melanomas (three, five, and three dogs diagnosed with clinical stage I, II, and III melanoma, respectively) were evaluated. Subcutaneous lupeol $(10 \mathrm{mg} / \mathrm{kg})$ was administered postoperatively at various time points. Of the 11 subjects, seven exhibited no local recurrence 180 days postoperatively and no severe adverse effects were observed in any of these cases. Furthermore, no metastases have been detected during the period of the trial.

The current and promising immunotherapy to further augment the options for treatment in malignant melanomas, at least in humans, has been based on checkpoint-blocking antibodies, which can restore anticancer immune responses. Immune checkpoint molecules regulate the immune response avoiding autoimmunity and deleterious effects of an inflammatory response, but when expressed on tumors cells they work as a mechanism of immune evasion. Good examples of immune checkpoint molecules include PD-1 immune checkpoint inhibitor antibody (Pembrolizumab- humanized IgG4; Nivolumab- human IgG4), which was the first drug to gain FDA approval to a phase I trial in patients with BRAF inhibitor-resistant advanced melanoma and BRAFV600 mutation-positive melanoma [121]; and a checkpoint inhibitor (ipilimumab) directed against the cytotoxic T lymphocyte Antigen (CTLA-4). Data from clinical trials has demonstrated the important role this therapeutic approach can play-even with the development of immune-related side effects-since it has been proved a meaningful clinical improvement and an impressive increase in overall survival in melanoma patients [122] when compared to conventional chemotherapy. In the veterinary medicine field, the perspective of this therapy was described by Maekawa et al. [123], who demonstrated that an antibovine PD-L1 monoclonal antibody effectively blocked the binding of recombinant PD-1 with PD-L1-expressing tumor cells in a dose-dependent manner, including canine melanoma cells.

Other therapy as future treatment strategy for canine malignant melanoma can be based on oncolytic virotherapy. Basically, the virus infects and kills tumor cells when replication, lysis, and release of viruses occur. Tumor oncolysis by reovirus infection that was related in Ras-transformed cells was studied in six canine malignant melanoma cell lines $\mathrm{CMeC1}, \mathrm{CMeC}$, $\mathrm{KMeC}, \mathrm{LMeC}, \mathrm{CMGD}$, and CMGD5. All of them were susceptible to reovirus infection, although Ras activation was not related in these cells, and only one of them (CMGD2) demonstrated more than $50 \%$ of cell death [124].

All efforts are geared toward better characterization of malignant melanomas in dogs, for the benefit of these companion animals, and also in an attempt to benefit the treatment of melanoma in humans.

\section{Conclusions}

Melanomas are very aggressive tumors and dogs are considered good models to study this disease. All efforts are geared toward better characterization and control of malignant melanomas in 
dogs, for the benefit of these companion animals, and also in an attempt to benefit the treatment of human melanomas.

Acknowledgments: Karen Batschinski is the recipient of a fellowship from Fundação de Amparo a Pesquisa do Estado de São Paulo, FAPESP, Proc. Number 2013/16423-8. The authors are grateful to Jose Guilherme Xavier for supplying photos of canine melanomas.

Author Contributions: Adriana Tomoko Nishiya, Claudia Ronca Felizzola, Eduardo Perlmann, Claudia Ronca Felizzola, Priscila Pedra Mendonça, Jéssica Soares Garcia, Tarso Felipe Teixeira, Maria Lucia Zaidan Dagli and Maria Lucia drafted the manuscript, Karen Batschinski, Marcello Vannucci Tedardi and the others revised the manuscript. All authors read and approved the final manuscript.

Conflicts of Interest: The authors declare no conflict of interest.

\section{References}

1. Sweet, M.; Kirkham, N.; Bendall, M.; Currey, L.; Bythell, J.; Heupel, M. PLoS ONE 2012. [CrossRef]

2. Starkey, M.P.; Scase, T.J.; Mellersh, C.S.; Murphy, S. Dogs really are man's best friend-Canine genomics has applications in veterinary and human medicine! Brief. Funct. Genomic. Proteomic. 2005, 4, 112-128. [CrossRef] [PubMed]

3. Paoloni, M.; Khanna, C. Translation of new cancer treatments from pet dogs to humans. Nat. Rev. Cancer 2008, 8, 147-156.

4. Nowend, K.L.; Starr-Moss, A.N.; Murphy, K.E. The function of dog models in developing gene therapy strategies for human health. Mamm. Genome 2011, 22, 476-485. [CrossRef] [PubMed]

5. Khanna, C.; Lindblad-Toh, K.; Vail, D.; London, C.; Bergman, P.; Barber, L.; Breen, M.; Kitchell, B.; McNeil, E.; Modiano, J.F.; et al. The dog as a cancer model. Nat. Biotechnol. 2006, 24, 1065-1066. [CrossRef] [PubMed]

6. Fowles, J.S.; Denton, C.L.; Gustafson, D.L. Comparative analysis of MAPK and PI3K/AKT pathway activation and inhibition in human and canine melanoma. Vet. Comp. Oncol. 2015, 13, 288-304. [CrossRef] [PubMed]

7. Haass, N.K.; Smalley, K.S.; Herlyn, M. The role of altered cell-cell communication in melanoma progression. J. Mol. Histol. 2004, 35, 309-318. [CrossRef] [PubMed]

8. Marcus, D.M.; Marcus, P.M.; Prabhu, R.S.; Owonikoko, T.K.; Lawson, D.H.; Switchenko, J.; Beither, J. Rising incidence of mucosal melanoma of the head and neck in the United States. J. Skin Cancer 2012, 231693.

9. Gavriel, H.; McArthur, G.; Sizeland, A.; Henderson, M. Review: Mucosal melanoma of the head and neck. Melanoma Res. 2011, 21, 257-266. [CrossRef] [PubMed]

10. Meleti, M.; Leemans, C.R.; De Bree, R.; Vescovi, P.; Sesenna, E.; van der Waal, I. Head and neck mucosal melanoma: Experience with 42 patients, with emphasis on the role of postoperative radiotherapy. Head Neck 2008, 30, 1543-1551. [CrossRef] [PubMed]

11. Ramos-Vara, J.A.; Beissenherz, M.E.; Miller, M.A.; Johnson, G.C.; Pace, L.W.; Fard, A.; Kottler, S.J. Retrospective study of 338 canine oral melanomas with clinical, histologic, and immunohistochemical review of 129 cases. Vet. Pathol. 2000, 37, 597-608. [CrossRef] [PubMed]

12. Kimura, K.C.; Garate, A.P.; Dagli, M.L.Z. Retrospective study of neoplasms in domestic animals: A survey between 1993 and 2002 of the service of animal pathology, department of pathology, school of veterinary medicine and animal science, University of Sao Paulo, Southeast Brazil. Braz. J. Vet. Pathol. 2012, 5, 60-69.

13. Teixeira, T.F.; Silva, T.C.; Cogliati, B.; Nagamine, N.K.; Dagli, M.L.Z. Retrospective study of melanocytic neoplasms in dogs and cats. Braz. J. Vet. Pathol. 2010, 3, 100-104.

14. Omholt, K.; Grafström, E.; Kanter-Lewensohn, L.; Hansson, J.; Ragnarsson-Olding, B.K. KIT pathway alterations in mucosal melanomas of the vulva and other sites. Clin. Cancer Res. 2011, 17, 3933-3942. [CrossRef] [PubMed]

15. Zanoni, M.T.; Medicina, D.; Lombardi, D.; Ungari, M.; Balzarini, P.; Rossini, C.; Pellegrini, W.; Battaglia, P.; Capella, C.; Castelnuovo, P.; et al. Sinonasal mucosal melanoma: Molecular profile and therapeutic implications from a series of 32 cases. Head Neck 2013, 35, 1066-1077. [CrossRef] [PubMed]

16. Lyu, J.; Wu, Y.; Li, C.; Wang, R.; Song, H.; Ren, G.; Guo, W. Mutation scanning of BRAF, NRAS, KIT, and GNAQ/GNA11 in oral mucosal melanoma: A study of 57 cases. J. Oral Pathol. Med. 2015. [CrossRef] [PubMed] 
17. Curtin, J.A.; Fridlyand, J.; Kageshita, T.; Patel, H.N.; Busam, K.J.; Kutzner, H.; Cho, K.H.; Aiba, S.; Bröcker, E.B.; LeBoit, P.E.; et al. Distinct sets of genetic alterations in melanoma. N. Engl. J. Med. 2005, 353, 2135-2147. [CrossRef] [PubMed]

18. Spangler, W.L.; Kass, P.H. The histologic and epidemiologic bases for prognostic consideration in canine melanocytic neoplasia. Vet. Pathol. 2006, 43, 136-149. [CrossRef] [PubMed]

19. Gillard, M.; Cadieu, E.; De Brito, C.; Abadie, J.; Vergier, B.; Devauchelle, P.; Degorce, F.; Dreano, S.; Primot, A.; Dorso, L.; et al. Naturally occurring melanomas in dogs as models for non-UV pathways of human melanomas. Pigment Cell Melanoma Res. 2014, 27, 90-102. [CrossRef] [PubMed]

20. Priester, W.A. Skin tumors in domesticated animals. Data from 12 United States and Canadian Colleges of Veterinary Medicine. J. Natl. Cancer Insit. 1973, 50, 457-466.

21. Goldschmidt, M.H. Pigmented lesions of the skin. Clin. Dermatol. 1994, 12, 507-514. [CrossRef]

22. Marino, D.J.; Matthiesen, D.T.; Stefanacci, J.D.; Moroff, S.D. Evaluation of dogs with digit masses: 117 cases (1981-1991). J. Am. Vet. Med. Assoc. 1995, 207, 726-728. [PubMed]

23. Miller, W.H.; Griffin, I.; Campbell, K.L. Muller and Kirk's Small Animal Dermatology, 7th ed.; Elsevier Mosby: St. Louis, MO, USA, 2013; pp. 774-843.

24. Teixeira, T.F.; Gentile, L.B.; Silva, T.C.; Mennecier, G.; Chaible, L.M.; Cogliati, B.; Roman, M.A.; Gioso, M.A.; Dagli, M.L.Z. Cell proliferation and expression of connexins differ in melanotic and amelanotic canine oral melanomas. Vet. Res. Commun. 2014, 38, 29-38. [CrossRef] [PubMed]

25. Tedardi, M.V.; Biondi, L.R.; Kimura, K.C.; Pedra Mendonça, P.; Grandi, F.; Latorre, A.M.; Dagli, M.L.Z. Comparative oncology in Sao Paulo, Brazil-What to learn from cancer registry. Source J. Vet. Sci. 2014, $1,1-8$.

26. Tedardi, M.V.; Veneziano, D.B.; Kimura, K.C.; Pedra Mendonça, P.; Biondi, L.R.; Grandi, F.; Latorre, A.M.; Dagli, M.L.Z. Sao Paulo animal cancer registry, the first in Latin America. Vet. Comp. Oncol. 2015, 13, 154-155. [CrossRef] [PubMed]

27. Haass, N.K.; Ripperger, D.; Wladykowski, E.; Dawson, P.; Gimotty, P.A.; Blome, C.; Fischer, F.; Schmage, P.; Moll, I.; Brandner, J.M. Melanoma progression exhibits a significant impact on connexin expression patterns in the epidermal tumor microenvironment. Histochem. Cell Biol. 2010, 133, 113-124. [CrossRef] [PubMed]

28. Modiano, J.F.; Ritt, M.G.; Wojcieszyn, J. The molecular basis of canine melanoma: Pathogenesis and trends in diagnosis and therapy. J. Vet. Intern. Med. 1999, 13, 163-174. [CrossRef] [PubMed]

29. Smith, H.; Goldschmidt, H.; Mcmanus, P.M. A Comparative review of melanocytic neoplasms. Vet. Pathol. 2002, 39, 651-678. [CrossRef] [PubMed]

30. Dzutsev, A.; Goldszmid, R.S.; Viaud, S.; Zivtogel, L.; Trinchieri, G. The role of the microbiota in inflammation, carcinogenesis, and cancer therapy. Eur. J. Immunol. 2015, 45, 17-31. [CrossRef] [PubMed]

31. Goldschmidt, M.H.; Hendrick, M.J. Tumors of the skin and soft tissues. In Tumors in Domestic Animals, 4th ed.; Meuten, D.J., Ed.; Iowa State Press: Ames, IA, USA, 2002; pp. 78-82.

32. Scott, D.W.; Miller, W.H., Jr.; Griffin, C.E. Muller \& Kirk's Small Animal Dermatology, 6th ed.; Elsevier Saunders: Philadelphia, PA, USA, 2001; pp. 1-70.

33. Li, G.; Herlyn, M. Dynamics of intercellular communication during melanoma development. Mol. Med. Today 2000, 6, 163-169. [CrossRef]

34. Chin, L. The genetics of malignant melanoma: Lessons from mouse and man. Nat. Rev. Cancer 2003, 3, 559-570. [CrossRef] [PubMed]

35. Gaggioli, C.; Sahai, E. Melanoma invasion-Current knowledge and future directions. Pigment Cell Res. 2007, 20, 161-172. [CrossRef] [PubMed]

36. Head, K.W.; Else, R.W.; Dubielzig, R.R. Tumors of the Alimentary Tract. In Tumors in Domestic Animals, 4th ed.; Meuten, D.J., Ed.; Iowa State Press: Ames, IA, USA, 2002; pp. 426-430.

37. Tajima, S.; Ura-Ishiko, A.; Hayashi, A. Melanogenesis, biosynthetic phenotype of fibronectin and collagen, and migrating activity in cloned B16 mouse melanoma cells. J. Dermatol. Sci. 1996, 12, 24-30. [CrossRef]

38. Simonetti, O.; Lucarini, G.; Brancorsini, D.; Nita, P.; Bernardini, M.L.; Biagini, G.; Offidani, A. Immunohistochemical expression of vascular endothelial growth factor, matrix metalloproteinase 2 and matrix metalloproteinase 9 in cutaneous melanocytic lesions. Cancer 2002, 95, 602-624. [CrossRef] [PubMed]

39. Nakhleh, R.E.; Wick, M.R.; Rocamora, A.; Swanson, P.E.; Dehner, L.P. Morphologic diversity in malignant melanomas. Am. J. Clin. Pathol. 1990, 93, 731-740. [PubMed] 
40. Chénier, S.; Doré, M. Oral Malignant Melanoma with Osteoid Formation in a Dog. Vet. Pathol. 1999, 36, 74-76. [CrossRef] [PubMed]

41. Smedley, R.C.; Spangler, W.L.; Esplin, D.G.; Kitchell, B.E.; Bergman, P.J.; Ho, H.Y.; Bergin, I.L.; Kiupel, M. Prognostic markers for canine melanocytic neoplasms: A comparative review of the literature and goals for future investigation. Vet. Pathol. 2011, 48, 54-72. [CrossRef] [PubMed]

42. Sandusky, G.E.; Carlton, W.W.; Wightman, K.A. Diagnostic immunohistochemistry of canine round cell tumors. Vet. Pathol. 1987, 24, 495-499. [PubMed]

43. Silva, A.P.; Silva, R.G.; Cogliati, B.; Dias, A.S.M.; Le Bas, A.E.; Hernandez-Blazquez, F.J. Bleaching of melanin in the epidermis of South American fur seal and its application on enzyme immunohistochemistry. Pesqui. Vet. Bras. 2011, 31, 267-270. [CrossRef]

44. Fisher, D.E.; Kwong, L.N.; Chin, L. Melanoma. In DeVita VT, Hellman and Rosenberg's Cancer Principles $\mathcal{E}$ Practice of Oncology, 8th ed.; De Vita, V.T., Jr., Lawrence, T.S., Rosenberg, S.A., Eds.; Lippincott Williams \& Wilkins: Philadelphia, PA, USA, 2008; pp. 1889-1951.

45. Shelly, S.; Chien, M.B.; Yip, B.; Kent, M.S.; Theon, A.P.; McCallan, J.L.; London, C.A. Exon 15 BRAF mutations are uncommon in canine oral malignant melanomas. Mamm. Genome 2004, 16, 211-217. [CrossRef] [PubMed]

46. Chu, P.Y.; Pan, S.L.; Liu, C.H.; Lee, J.; Yeh, L.S.; Liao, A.T. KIT gene exon 11 mutations in canine malignant melanoma. Vet. J. 2013, 196, 226-230. [CrossRef] [PubMed]

47. Curtin, J.A.; Busam, K.; Pinkel, D.; Bastian, B.C. Somatic activation of KIT in distinct subtypes of melanoma. J. Clin. Oncol. 2006, 24, 4340-4346. [CrossRef] [PubMed]

48. Maldonado, J.L.; Fridlyand, J.; Patel, H.; Jain, A.N.; Busam, K.; Kageshita, T.; Ono, T.; Albertson, D.G.; Pinkel, D.; Bastian, B.C. Determinants of BRAF mutations in primary melanomas. J. Natl. Cancer Inst. 2003, 95, 1878-1890. [CrossRef] [PubMed]

49. Murakami, A.; Mori, T.; Sakai, H.; Murakami, M.; Yanai, T.; Hoshino, Y.; Maruo, K. Analysis of KIT expression and KIT exon 11 mutations in canine oral malignant melanomas. Vet. Comp. Oncol. 2011, 9, 219-224. [CrossRef] [PubMed]

50. Zebary, A.; Jangard, M.; Omholt, K.; Ragnarsson-Olding, B.; Hansson, J. KIT, NRAS and BRAF mutations in sinonasal melanoma. Br. J. Cancer 2013, 109, 559-564. [CrossRef] [PubMed]

51. Goel, V.K.; Lazar, A.J.; Warneke, C.L.; Redston, M.S.; Haluska, F.G. Examination of mutations in BRAF, NRAS, and PTEN in primary cutaneous melanoma. J. Investig. Dermatol. 2006, 126, 154-160. [CrossRef] [PubMed]

52. Mochizuki, H.; Kennedy, K.; Shapiro, S.G.; Breen, M. BRAF Mutations in Canine Cancers. PLoS ONE 2015. [CrossRef] [PubMed]

53. Bergman, P.J. Canine Oral Melanoma. Clin. Tech. Small Anim. Pract. 2007, 22, 55-60. [CrossRef] [PubMed]

54. Todoroff, R.J.; Brodey, R.S. Oral and pharyngeal neoplasia in the dog: A retrospective survey of 361 cases. J. Am. Vet. Med. Assoc. 1979, 175, 567-571. [PubMed]

55. Vos, J.H.; Gaag, I.V.D. Canine and feline oral-pharyngeal tumours. J. Vet. Med. 1987, 34, 420-427. [CrossRef]

56. Guerra, J.L.; Dagli, M.L.; Godoy, L.F.; Birman, E.G. A retrospective study of oral neoplasms in dogs: A survey from 1941 to 1986. Rev. Fac. Med. Vet. Zootec. Univ. S. Paulo 1989, 26, 207-212.

57. Stopiglia, A.J.; Felizzola, C.R.; Dagli, M.L.Z.; Xavier, J.G.; Guerra, J.L.; Birman, E. Estudo clínico e anátomo-patológico das formações neoplásicas e não neoplásicas da cavidade bucal de cães. Comun. Cient. Fac. Med. Vet. Zootec. USP 1992, 16, 33-39.

58. Ghirelli, C.D.O. In Biblioteca Digital USP. Available online: http://www.teses.usp.br/teses/disponiveis/10/ 10137/tde-22072008-090727/pt-br.php (assecced on 15 November 2015).

59. Requicha, J.F.M.F. Repositório Universidade de Trás-os-Montes e Alto Douro. Available online: https:// repositorio.utad.pt/bitstream/10348/711/1/MsC_jfmfrequicha.pdf (accessed on 15 November 2015).

60. Bronden, L.B.; Eriksen, T.; Kristensen, A.T. Oral malignant melanomas and other head and neck neoplasms in Danish dogs-data from the Danish Veterinary Cancer Registry. Acta Vet. Scand. 2009, 51, 1-6. [CrossRef] [PubMed]

61. Liptak, J.M.; Withrow, S.J. Cancer of gastrointestinal tract. In Small Animal Clinical Oncology, 5th ed.; Withrow, S.J., Vail, D.M., Page, R.L., Eds.; Elsevier Saunders: St. Louis, MO, USA, 2013; pp. 381-395.

62. McEntee, M.C. Clinical behavior of nonodontogenic tumors. In Oral and Maxillofacial Surgery in Dogs and Cats; Verstraete, F.J.M., Lommer, M.J., Eds.; Elsevier Saunders: Pennsylvania, PA, USA, 2012; pp. 387-402. 
63. Dennis, M.; Ehrhart, N.; Duncan, C.; Barnes, A.; Ehrhart, E. Frequency of and risk factors associated with lingual lesions in dogs: 1196 cases (1995-2004). J. Am. Vet. Med. Assoc. 2006, 228, 1533-1537. [CrossRef] [PubMed]

64. Williams, L.E.; Packer, R.A. Association between lymph node size and metastasis in dogs with oral malignant melanoma: 100 cases (1987-2001). J. Am. Vet. Med. Assoc. 2003, 222, 1234-1236. [CrossRef] [PubMed]

65. Esplin, D.G. Survival of dogs following surgical excision of histologically well-differentiated melanocytic neoplasms of the mucous membranes of the lips and oral cavity. Vet. Pathol. 2008, 45, 889-896. [CrossRef] [PubMed]

66. White, R.A.S.; Jefferies, A.R.; Freedman, L.S. Clinical staging for oropharyngeal malignancies in the dog. J. Small Anim. Pract. 1985, 26, 581-594. [CrossRef]

67. MacEwen, E.G.; Patnaik, A.K.; Harvey, H.J.; Hayes, A.A.; Matus, R. Canine oral melanoma: Comparison of surgery versus surgery plus Corynebacterium parvum. Cancer Investig. 1986, 4, 397-402. [CrossRef]

68. Hahn, K.A.; Denicola, D.B.; Richardson, R.C.; Hahn, E.A. Canine oral malignant melanoma: Prognostic utility of an alternative staging system. J. Small Anim. Pract. 1994, 35, 251-256. [CrossRef]

69. Boston, S.E.; Lu, X.; Culp, W.T.N.; Montinaro, V.; Romanelli, G.; Dudley, R.M.; Liptak, J.M.; Mestrinho, L.A.; Buracco, P. Efficacy of systemic adjuvant therapies administered to dogs after excision of oral malignant melanomas: 151 cases (2001-2012). J. Am. Vet. Med. Assoc. 2014, 245, 401-407. [CrossRef] [PubMed]

70. Owen, L.N. TNM Classification of Tumours in Domestic Animals; World Health Organization: Geneve, Switzerland, 1980.

71. Tuohy, J.L.; Selmic, L.E.; Worley, D.R.; Ehrhart, N.P.; Withrow, S.J. Outcome following curative-intent surgery for oral melanoma in dogs: 70 cases (1998-2011). J. Am. Vet. Med. Assoc. 2014, 245, 1266-1273. [CrossRef] [PubMed]

72. Harvey, H.J.; MacEwen, E.G.; Braun, D.; Patnaik, A.K.; Withrow, S.J.; Jongeward, S. Prognostic criteria for dogs with oral melanoma. J. Am. Vet. Med. Assoc. 1981, 178, 580-582. [PubMed]

73. Mould, J.R.B.; Petersen-Jones, S.M.; Peruccio, C.; Ratto, A.; Sassani, J.W.; Harbour, J.W. Uveal melanocytic tumors. In Ocular Tumors in Animals and Humans; Peiffer, R.L., Jr., Simons, K.B., Eds.; Iowa State Press: Ames, IA, USA, 2002; pp. 225-282.

74. Dubielzig, R.R.; Ketring, K.L.; Mclellan, G.J.; Albert, D.M. Veterinary Ocular Pathology: A Comparative Review; W.B. Saunders: Philadelphia, PA, USA, 2010; p. 472.

75. Wilcock, B.P.; Peiffer, J.R. Morphology and behavior of primary ocular melanomas in 91 dogs. Vet. Pathol. 1986, 23, 418-424. [CrossRef] [PubMed]

76. Garner, A.; Koornneef, L.; Levene, A.; Collin, J.R. Malignant melanoma of the eyelid skin: Histopathology and behaviour. Br. J. Ophthalmol. 1985, 69, 180-186. [CrossRef] [PubMed]

77. Conceição, L.F.; Ribeiro, A.P.; Piso, D.Y.T.; Laus, J.L. Considerations about ocular neoplasia of dogs and cats. Cienc. Rural 2010, 40, 2235-2242. [CrossRef]

78. Lim, L.A.; Madigan, M.C.; Conway, R.M. Conjunctival melanoma: A review of conceptual and treatment advances. Clin. Ophthalmol. 2013, 7, 521-531. [CrossRef] [PubMed]

79. Donaldson, D.; Sansom, J.; Scase, T.; Adams, V.; Mellersh, C. Canine Limbal melanoma: 30 cases (1992-2004). Part 1. Signalment, clinical and histological features and pedigree analysis. Vet. Ophthalmol. 2006, 9, 115-119. [CrossRef] [PubMed]

80. Perlmann, E.; Barros, P.S.M.; Fernandez, L.; Di Cesare, S.; Bakalian, S.; Burnier, M.N., Jr. Histopathological evaluation of pigmented intraocular tumors in dogs. Investig. Ophthalmol. Vis. Sci. 2010, 5, 5159.

81. Esson, D.; Fahrer, C.; Zarfoss, M.K.; Dubielzig, R.R. Suspected uveal metastasis of a nail bed melanoma in a dog. Vet. Ophthalmol. 2007, 10, 262-266. [CrossRef] [PubMed]

82. Fineman, M.S.; Eagle, R.C.; Shields, J.A.; Shields, C.L.; Potter, P. Melanocytomalytic glaucoma in eyes with necrotic iris melanocytoma. Ophthalmology 1998, 105, 492-496. [CrossRef]

83. Ryan, A.M.; Diters, R.W. Clinical and pathologic features of canine ocular melanomas. J. Am. Med. Assoc. 1984, 184, 60-67.

84. Giuliano, E.A.; Chappell, R.; Fischer, B.; Dubielzig, R.R. A matched observational study of canine survival with primary intraocular melanocytic neoplasia. Vet. Ophthalmol. 1999, 2, 185-190. [CrossRef] [PubMed]

85. Konrade, K.A.; Hoffman, A.; Schubert, C.S.; Dubielzig, R.R. A histologic series of secondary uveal melanomas in eleven dogs. In Proceedings of the 40th Annual Meeting of the American College of Veterinary Ophthalmologist, Chicago, IL, USA, 4-7 November 2009. 
86. Willis, A.M.; Wilkie, D.A. Ocular oncology. Clin. Tech. Small Anim. Pract. 2001, 16, 77-85. [CrossRef] [PubMed]

87. Cazalot, G.; Raymond-Letron, I.; Regnier, A. Choroidal melanoma presented as glaucoma in a dog: Case report and review of the literature. Rev. Med. Vet. 2008, 159, 74-78.

88. Henry, C.J.; Brewer, W.G.; Whitley, E.M.; Tyler, J.W.; Ogilvie, G.K.; Norris, A.; Fox, L.E.; Morrison, W.B.; Hammer, A.; Vail, D.M.; et al. Canine digital tumors: Veterinary cooperative oncology group retrospective study of 64 dogs. J. Vet. Intern. Med. 2005, 19, 720-724. [CrossRef] [PubMed]

89. Aronsohn, M.G.; Carpenter, J.L. Distal extremity melanocytic nevi an malignant melanomas in dogs. J. Am. Anim. Hosp. Assoc. 1990, 26, 605-612.

90. Wobeser, B.K.; Kidney, B.A.; Powers, B.E.; Withrow, S.J.; Mayer, M.N.; Spinato, M.T.; Allen, A.L. Diagnosis and clinical outcomes associated with surgically amputated canine digit submitted to multiple veterinary diagnostic laboratories. Vet. Pathol. 2007, 44, 355-361. [CrossRef] [PubMed]

91. Manley, C.A.M.; Leibman, N.F.; Wolchok, J.D.; Riviere, I.C.M.; Bartido, S.; Craft, D.M.; Bergman, P.J. Xenogeneic Murine Tyrosinase DNA Vaccine for Malignant Melanoma of the Digit of Dogs. J. Vet. Intern. Med. 2011, 25, 94-99. [CrossRef] [PubMed]

92. Bostock, D.E. Prognosis after surgical excision of canine melanoma. Vet. Pathol. 1979, 16, 32-40. [PubMed]

93. Bergman, P.J.; Kent, M.S.; Farese, J.P. Melanoma. In Small Animal Clinical Oncology, 5th ed.; Withrow, S.J., Vail, D.M., Page, R.L., Eds.; Elsevier Saunders: St. Louis, MO, USA, 2013; pp. 321-334.

94. Brockley, L.K.; Cooper, M.A.; Bennett, P.F. Malignant melanoma in 63 dogs (2001-2011): The effect of carboplatin chemotherapy on survival chemotherapy on survival. N. Z. Vet. J. 2013, 61, 25-31. [CrossRef] [PubMed]

95. Smith, M.M. Surgical approach for lymph node staging of oral and maxillofacial neoplasms in dogs. J. Am. Anim. Hosp. Assoc. 1995, 31, 514-518. [CrossRef] [PubMed]

96. Herring, E.S.; Smith, M.M.; Robertson, J.L. Lymph node staging of oral and maxillofacial neoplasms in 31 dogs and cats. J. Vet. Dent. 2002, 19, 122-126. [PubMed]

97. Proulx, D.R.; Ruslander, D.M.; Dodge, R.K.; Hauck, M.L.; Williams, L.E.; Horn, B.; Price, G.S.; Thrall, D.E. A retrospective analysis of $140 \mathrm{dogs}$ with oral melanoma treated with external beam radiation. Vet. Radiol. Ultrasound. 2003, 44, 352-359. [CrossRef]

98. Théon, A.P.; Rodriguez, C.; Madewell, B.R. Analysis of prognostic factors and patterns of failure in dogs with malignant oral tumors treated with megavoltage irradiation. J. Am. Vet. Med. Assoc. 1997, 210, 778-784. [PubMed]

99. Khan, N.; Mohammad, K.K.; Almasan, A.; Singh, A.D.; Macklis, R. The evolving role of radiation therapy in the management of malignant melanoma. Int. J. Radiat. Oncol. Biol. Phys. 2011, 80, 645-654. [PubMed]

100. Bateman, K.E.; Catton, P.A.; Pennock, P.W.; Kruth, S.A. 0-7-21 radiation therapy for the treatment of canine oral melanoma. J. Vet. Intern. Med. 1994, 8, 267-272. [CrossRef] [PubMed]

101. Murphy, S.; Hayes, A.M.; Blackwood, L.; Maglennon, G.; Pattinson, H.; Sparkes, A.H. Oral malignant melanoma: The effect of coarse fractionation alone or with adjuvant carboplatin therapy. Vet. Comp. Oncol. 2005, 3, 222-229. [CrossRef] [PubMed]

102. Cancedda, S.; Bley, C.R.; Aresu, L.; Dacasto, M.; Leone, V.F.; Pizzoni, S.; Gracis, M.; Marconato, L. Efficacy and side effects of radiation therapy in comparison with radiation therapy and temozolomide in the treatment of measurable canine malignant melanoma. Vet. Comp. Oncol. 2014. [CrossRef] [PubMed]

103. Freeman, K.P.; Hahn, K.A.; Harris, F.D.; King, G.K. Treatment of dogs with oral melanoma by hypofractionated radiation therapy and platinum-based chemotherapy (1987-1997). J. Vet. Intern. Med. 2003, 17, 96-101. [PubMed]

104. Rassnick, K.M.; Ruslender, D.M.; Cotter, S.M.; Al-Sarraf, R.; Bruyette, D.S.; Gamblin, R.M.; Meleo, K.A.; Moore, A.S. Use of carboplatin for treatment of dogs with malignant melanoma: 27 cases (1989-2000). J. Am. Vet. Med. Assoc. 2001, 218, 1444-1448. [CrossRef] [PubMed] 
105. Boria, P.A.; Murry, D.J.; Bennett, P.F.; Glickman, N.W.; Snyder, P.W.; Merkel, B.L.; Schlittler, D.L.; Mutsaers, A.J.; Thomas, R.M.; Knapp, D.W. Evaluation of cisplatin combined with piroxicam for the treatment of oral malignant melanoma and oral squamous cell carcinoma in dogs. J. Am. Vet. Med. Assoc. 2004, 224, 388-394. [CrossRef] [PubMed]

106. Dank, G.; Rassnick, K.M.; Sokolovsky, Y.; Garrett, L.D.; Post, G.S.; Kitchell, B.E.; Sellon, R.K.; Kleiter, M.; Northrup, N.; Segev, G. Use of adjuvant carboplatin for treatment of dogs with oral malignant melanoma following surgical excision. Vet. Comp. Oncol. 2014, 12, 78-84. [CrossRef] [PubMed]

107. Bergman, P.J.; Mcknight, J.; Novosad, A.; Charney, S.; Farrelly, J.; Craft, D.; Wulderk, M.; Jeffers, Y.; Sadelain, M.; Hohenhaus, A.E.; et al. Long-term survival of dogs with advanced malignant melanoma after DNA vaccination with xenogeneic human tyrosinase: A phase I trial. Clin. Cancer Res. 2003, 9, 1284-1290. [PubMed]

108. MacEwen, E.G.; Kurzman, I.D.; Vail, D.M.; Dubielzig, R.R.; Everlith, K.; Madewell, B.R.; Rodriguez, C.O., Jr.; Phillips, B.; Zwahlen, C.H.; Obradovich, J.; et al. Adjuvant therapy for melanoma in dogs: Results of randomized clinical trials using surgery, liposome-encapsulated muramyl triptide, and granulocyte macrophage colony-stimulang factor. Clin. Cancer Res. 1999, 5, 4249-4258. [PubMed]

109. Moff, S.L.; Corey, G.R.; Gottfredsson, M. Distant cutaneous granulomas after bacille Calmette-Guérin immunotherapy for malignant melanoma: Case for direct infection. Clin. Infect. Dis. 1999, 29, 1569-1570. [CrossRef] [PubMed]

110. Bianco, S.R.; Sun, J.; Fosmire, S.P.; Hance, K.; Padilla, M.L.; Ritt, M.G.; Getzy, D.M.; Duke, R.C.; Withrow, S.J.; Lana, S.; et al. Enhancing anti melanoma immune responses through apoptosis. Cancer Gene Ther. 2003, 10, 726-736. [CrossRef] [PubMed]

111. Alexander, A.N.; Huelsmeyr, M.K.; Mitzey, A.; Dubielzig, R.R.; Kurzman, I.D.; MacEwen, E.G.; Vail, D.M. Development of an allogenic whole-cell tumor vaccine expressing xenogenic gp100 and implementation in phase II clinical trial in canine patients with malignant melanoma. Cancer Immunol. Immunother. 2006, 55, 433-442. [CrossRef] [PubMed]

112. Hogge, G.S.; Burkholder, J.K.; Culp, J.; Albertini, M.R.; Dubielzig, R.R.; Keller, E.T.; Yang, N.S.; MacEwen, E.G. Development of human granulocyte-macrophage colony-stimulating factor- transfected tumor cell vaccines for treatment of spontaneous canine cancer. Hum. Gene Ther. 1998, 9, 1851-1861. [CrossRef] [PubMed]

113. Bergman, P.J.; Wolchok, J.D. Of mice and men (and dogs): Development of a xenogeneic DNA vaccine for canine oral malignant melanoma. Cancer Ther. 2008, 6, 817-826.

114. Grosenbaugh, D.A.; Leard, A.T.; Bergman, P.J.; Klein, M.K.; Meleo, K.; Susaneck, S.; Hess, P.R.; Jankowski, M.K.; Jones, P.D.; Leibman, N.; et al. Safety and efficacy of a xenogeneic DNA vaccine encoding for human tyrosinase as adjunctive treatment for oral malignant melanoma in dogs following surgical excision of the primary tumor. Am. J. Vet. Res. 2011, 72, 1631-1638. [CrossRef] [PubMed]

115. Ottnod, J.M.; Smedley, R.C.; Walshaw, R.; Hauptman, J.G.; Kiupel, M.; Obradovich, J.E. A retrospective analysis of the efficacy of Oncept vaccine for the adjunct treatment of canine oral malignant melanoma. Vet. Comp. Oncol. 2013, 11, 219-229. [CrossRef]

116. Rotte, A.; Bhandaru, M.; Zhou, Y.; Mcelwee, K.J. Immunotherapy of melanoma: Present options and future promises. Cancer Metastasis Rev. 2015, 34, 115-128. [CrossRef] [PubMed]

117. Gyorffy, S.; Rodriguez-Lecompte, J.C.; Woods, J.P.; Foley, R.; Kruth, S.; Liaw, P.C.; Gauldie, J. Bone marrow-derived dendritic cell vaccination of dogs with naturally occurring melanoma by using human gp100 antigen. J. Vet. Intern. Med. 2005, 19, 56-63. [PubMed]

118. Tamura, K.; Yamada, M.; Isotani, M.; Arai, H.; Yagihara, H.; Ono, K.; Washizu, T.; Bonkobara, M. Induction of dendritic cell-mediated immune responses against canine malignant melanoma cells. Vet. J. 2008, 175, 126-129. [CrossRef] [PubMed]

119. Elmslie, R. VRCC Veterinary Speciality \& Emergency Hospital. Available online: http://www. vetcancerspecialists.com/blog/2013/1/31/the-controversy-surrounding-the-melanoma-vaccine-for-dogs / (accesse on 15 November 2015).

120. Yokoe, I.; Azuma, K.; Hata, K.; Mukaiyama, T.; Goto, T.; Tsuka, T.; Imagawa, T.; Itoh, N.; Murahata, Y.; Osaki, T.; et al. Clinical systemic lupeol administration for canine oral malignant melanoma. Mol. Clin. Oncol. 2015, 3, 89-92. [CrossRef] [PubMed] 
121. Robert, C.; Ribas, A.; Wolchok, J.D.; Hodi, F.S.; Hamid, O.; Kefford, R.; Weber, J.S.; Joshua, A.M.; Hwu, W.J.; Gangadhar, T.C.; et al. Anti-programmed-death-receptor-1 treatment with pembrolizumab in ipilimumab-refractory advanced melanoma: A randomised dose-comparison cohort of a phase 1 trial. Lancet 2014, 384, 1109-1117. [CrossRef]

122. Schadendorf, D.; Hodi, F.S.; Robert, C.; Weber, J.S.; Margolin, K.; Hamid, O.; Patt, D.; Chen, T.T.; Berman, D.M.; Wolchok, J.D. Pooled analysis of long-term survival data from phase II and phase III trials of ipilimumab in unresectable or metastatic melanoma. J. Clin. Oncol. 2015, 33, 1889-1894. [CrossRef] [PubMed]

123. Maekawa, N.; Konnai, S.; Ikebuchi, R.; Okagawa, T.; Adachi, M.; Takagi, S.; Kagawa, Y.; Nakajima, C.; Suzuki, Y.; Murata, S.; et al. Expression of PD-L1 on canine tumor cells and enhancement of IFN-c production from tumor infiltrating cells by PD-L1 blockade. PLoS ONE 2014. [CrossRef] [PubMed]

124. Igase, M.; Hwang, C.C.; Coffey, M.; Okuda, M.; Noguchi, S.; Mizuno, T. The oncolytic effects of reovirus in canine solid tumor cell lines. J. Vet. Med. Sci. 2015, 77, 541-548. [CrossRef] [PubMed]

(C) 2016 by the authors; licensee MDPI, Basel, Switzerland. This article is an open access article distributed under the terms and conditions of the Creative Commons by Attribution (CC-BY) license (http://creativecommons.org/licenses/by/4.0/). 